\title{
$\alpha$-Synuclein Negatively Regulates Protein Kinase C $\delta$ Expression to Suppress Apoptosis in Dopaminergic Neurons by Reducing p300 Histone Acetyltransferase Activity
}

\author{
Huajun Jin, ${ }^{1}$ Arthi Kanthasamy, ${ }^{1}$ Anamitra Ghosh, ${ }^{1}$ Yongjie Yang, ${ }^{2}$ Vellareddy Anantharam, ${ }^{1}$ \\ and Anumantha G. Kanthasamy ${ }^{1}$ \\ 'Parkinson's Disorder Research Laboratory, Iowa Center for Advanced Neurotoxicology, Department of Biomedical Sciences, Iowa State University, Ames, \\ Iowa 50011, and ${ }^{2}$ Department of Neurology and Neuroscience, The Johns Hopkins University, Baltimore, Maryland 21287
}

We recently demonstrated that protein kinase $\mathrm{C} \delta(\mathrm{PKC} \delta)$, an important member of the novel PKC family, is a key oxidative stresssensitive kinase that can be activated by caspase-3-dependent proteolytic cleavage to induce dopaminergic neuronal cell death. We now report a novel association between $\alpha$-synuclein ( $\alpha$ syn), a protein associated with the pathogenesis of Parkinson's disease, and PKC $\delta$, in which $\alpha$ syn negatively modulates the p300- and nuclear factor- $\kappa \mathrm{B}(\mathrm{NF} \kappa \mathrm{B})$-dependent transactivation to downregulate proapoptotic kinase PKC $\delta$ expression and thereby protects against apoptosis in dopaminergic neuronal cells. Stable expression of human wild-type $\alpha$ syn at physiological levels in dopaminergic neuronal cells resulted in an isoform-dependent transcriptional suppression of PKC $\delta$ expression without changes in the stability of mRNA and protein or DNA methylation. The reduction in PKC $\delta$ transcription was mediated, in part, through the suppression of constitutive NF $\kappa \mathrm{B}$ activity targeted at two proximal PKC $\delta$ promoter $\kappa \mathrm{B}$ sites. This occurred independently of $\mathrm{NF} \kappa \mathrm{B} / \mathrm{I} \kappa \mathrm{B} \alpha$ (inhibitor of $\kappa \mathrm{B} \alpha$ ) nuclear translocation but was associated with decreased NF $\kappa \mathrm{B}$-p65 acetylation. Also, $\alpha$ syn reduced p300 levels and its HAT (histone acetyltransferase) activity, thereby contributing to diminished PKC $\delta$ transactivation. Importantly, reduced $\mathrm{PKC} \delta$ and $\mathrm{p} 300$ expression also were observed within nigral dopaminergic neurons in $\alpha$ syn-transgenic mice. These findings expand the role of $\alpha$ syn in neuroprotection by modulating the expression of the key proapoptotic kinase PKC $\delta$ in dopaminergic neurons.

\section{Introduction}

Environmental neurotoxic insults and genetic defects in certain genes have been implicated in the etiology of Parkinson's disease (PD) (Dauer and Przedborski, 2003; Hatcher et al., 2008). Oxidative stress serves as a central mediator of degenerative processes in PD (Greenamyre and Hastings, 2004; Burke, 2008; Zhou et al., 2008); however, the key cell signaling mechanisms underlying oxidative damage to nigral dopaminergic neurons are not entirely clear. Our laboratory has been studying protein kinase $\mathrm{C} \delta$ $(\mathrm{PKC} \delta)$-mediated cell death signaling in the oxidative damage of dopaminergic neurons. $\mathrm{PKC} \delta$, a novel PKC isoform, has been recognized as a key proapoptotic effector in various cell types (Brodie and Blumberg, 2003; Kanthasamy et al., 2003). The role of PKC $\delta$ in nervous system function is beginning to emerge, and we demonstrated that $\mathrm{PKC} \delta$ is an oxidative stress-sensitive kinase that is persistently activated by caspase-3-dependent proteolytic cleavage to mediate dopaminergic neurodegeneration in cellular

Received 0ct. 27, 2010; accepted Nov. 22, 2010.

This work was supported by National Institutes of Health Grants NS38644 (A.G.K.), NS65167 (A.K.), and ES10586 (A.G.K.). The W. Eugene and Linda Lloyd Endowed Chair (A.G.K.) is also acknowledged. We thank MaryAnn deVries for assistance in the preparation of this manuscript.

Correspondence should be addressed to Dr. Anumantha G. Kanthasamy, Parkinson's Disorder Research Laboratory, Department of Biomedical Sciences, lowa State University, 2062 College of Veterinary Medicine Building, Ames, IA 50011. E-mail: akanthas@iastate.edu.

DOI:10.1523/JNEUROSCI.5634-10.2011

Copyright $\odot 2011$ the authors $\quad 0270-6474 / 11 / 312035-17 \$ 15.00 / 0$ models of PD (Anantharam et al., 2002; Kanthasamy et al., 2003; Kaul et al., 2003). We showed that cytochrome $c$ release and caspase- 9 and caspase- 3 activation serve as upstream events of the $\mathrm{PKC} \delta$-mediated cell pathway during mitochondrial impairment [e.g., 1-methyl-4-phenylpyridinium $\left(\mathrm{MPP}^{+}\right)$] in dopaminergic neuronal cells (Kaul et al., 2003). Importantly, depletion of PKC $\delta$ by small interfering RNA (siRNA) or blockage of PKC $\delta$ activation by overexpression of a PKC $\delta$ kinase dominant-negative mutant or caspase cleavage-resistant mutant protects against multiple insults in cultured neurons (Kitazawa et al., 2003; Yang et al., 2004; Latchoumycandane et al., 2005). Furthermore, pharmacological inhibition of PKC $\delta$ prevents MPTP (1-methyl-4-phenyl-1,2,3,6tetrahydropyridine)-induced degeneration of nigrostriatal dopaminergic neurons in animal models (Zhang et al., 2007b). We also showed that $\mathrm{PKC} \delta$ inhibits tyrosine hydroxylase $(\mathrm{TH})$ activity and dopamine synthesis in dopaminergic neurons (Zhang et al., 2007a). Despite the known proapoptotic function of PKC $\delta$ in dopaminergic neurons, the role of this kinase in cellular stress induced by proteins associated with familial PDlinked genes is not known.

$\alpha$-Synuclein ( $\alpha$ syn) is a presynaptic protein predominantly expressed in neurons throughout the mammalian brain. The physiological functions of $\alpha$ syn are poorly understood, but evidence has suggested a role for it in synaptic plasticity, dopamine synthesis, and membrane trafficking (Clayton and George, 1998; Perez et al., 2002; Outeiro and Lindquist, 2003). The relevance of 
$\alpha$ syn to PD pathogenesis is based on case studies of familial PD resulting from mutations or multiplications of $\alpha$ syn gene, as well as the observation that misfolded $\alpha$ syn is a major constituent of Lewy bodies in both familial and sporadic PD (Spillantini et al., 1998; Norris et al., 2004). Although altered $\alpha$ syn processing is thus considered a main determinant of $\mathrm{PD}$, a growing body of evidence suggests a protective role of native $\alpha$ syn in neurodegeneration (Manning-Bog et al., 2003; Sidhu et al., 2004; Chandra et al., 2005; Leng and Chuang, 2006; Monti et al., 2007).

While studying the PKC $\delta$-dependent cell death mechanisms, we unexpectedly found striking neuroprotection in an $\alpha$ synexpressing dopaminergic cell model during exposure to the parkinsonian neurotoxicant $\mathrm{MPP}^{+}$. This led us to further investigate the molecular mechanisms underlying the neuroprotective function mediated by $\alpha$ syn in dopaminergic neurons using cell culture and animal models. In the present study, we demonstrate a novel functional association between PKC $\delta$ and $\alpha$ syn in which $\alpha$ syn represses PKC $\delta$ expression by a mechanism involving modulation of both nuclear factor $-\kappa \mathrm{B}(\mathrm{NF} \kappa \mathrm{B})$ and p300 signaling pathways in a dopaminergic neuronal cell model and in transgenic $\alpha$ syn mice. We also show that the deregulation of proapoptotic $\mathrm{PKC} \delta$ expression protects dopaminergic neurons against $\mathrm{MPP}^{+}$toxicity. These observations extend the physiological role of native $\alpha$ syn in protecting against neuronal injury.

\section{Materials and Methods}

Reagents. $\mathrm{MPP}^{+}$, actinomycin D (ActD), protein A/G beads, sodium butyrate, and mouse $\beta$-actin antibody were purchased from SigmaAldrich. SN-50 peptide, garcinol, and N-(4-chloro-3-trifluoromethylphenyl)-2-ethoxy-6-pentadecyl-benzamide (CTPB) were obtained from Enzo Life Sciences. Biotin-16-UTP and the Cell Death Detection ELISA Plus assay kit were purchased from Roche Molecular Biochemicals. Z-DEVD-FMK was obtained from Alexis Biochemicals. Acetyl-DEVDamino-4-methylcoumarin (Ac-DEVD-AMC) was obtained from Bachem. The Bradford protein assay kit was purchased from Bio-Rad Laboratories. The DNeasy Blood \& Tissue kit was obtained from QIAGEN. Hoechst 33342, Lipofectamine Plus reagent, Lipofectamine 2000 reagent, hygromycin B, penicillin, streptomycin, fetal bovine serum, L-glutamine, RPMI 1640 medium, methionine-free RPMI 1640 medium, Neurobasal medium, B27 supplement, and DMEM were purchased from Invitrogen. Dynabeads M-280 was purchased from Dynal Biotech. $\left[{ }^{3} \mathrm{H}\right]$ Acetyl-CoA, poly $(\mathrm{dI}-\mathrm{dC}),\left[{ }^{35} \mathrm{~S}\right]$ methionine, HRP-linked anti-mouse and anti-rabbit secondary antibodies, and the ECL chemiluminescence kit were obtained from GE Healthcare. Antibodies to PKC $\delta, \operatorname{PKC} \alpha, \mathrm{PKC} \beta \mathrm{I}, \mathrm{PKC} \zeta$, p65, p50, inhibitor of $\kappa \mathrm{B} \alpha(\mathrm{I} \kappa \mathrm{B} \alpha)$, cAMP response element-binding proteinbinding protein (CBP), p300, and $\alpha$ syn (sc-12767; only detecting $\alpha$ syn of human origin) were purchased from Santa Cruz Biotechnology; the rabbit polyclonal antibody for acetyl-lysine, mouse p300, and histone $\mathrm{H} 3$ antibodies were obtained from Millipore. $\alpha$ Syn monoclonal antibody detecting both human and rat origins was purchased from BD Biosciences (Syn-1); the mouse TH antibody was obtained from Millipore Bioscience Research Reagents; the goat polyclonal antibody for lactate dehydrogenase $(\mathrm{LDH})$ and mouse monoclonal antibody for Lamin B1 were purchased from Abcam. IRDye800-conjugated anti-rabbit secondary antibody was obtained from Rockland Labs. Alexa 680-conjugated anti-mouse, Alexa 488-conjugated anti-mouse, Alexa 568-conjugated anti-rabbit secondary antibodies and mouse V5 antibody were obtained from Invitrogen. Anti-goat secondary antibody and normal rabbit IgG were obtained from Santa Cruz Biotechnology.

Plasmids. The plasmid encoding wild-type human $\alpha$ syn protein (pCEP4- $\alpha$ syn) was a kind gift from Dr. Eliezer Masliah (University of California, San Diego, La Jolla, CA). A control pCEP4 empty vector was purchased from Invitrogen. To prepare pLenti-V5-PKC $\delta$ and pLentiV5- $\alpha$ syn lentiviral vectors, full-length mouse PKC $\delta$ (gi: 6755081) and human $\alpha$ syn (gi: 6806897) cDNA were PCR-generated from pGFPPKC $\delta$ (kind gift from Dr. Mary E. Reyland, University of Colorado
Health Sciences Center, Denver, CO) and pCEP4- $\alpha$ syn with the following primer pairs, respectively: for $\mathrm{PKC} \delta$, forward, $5^{\prime}$-CACCATGGCACCCTTCCTGCGC-3', reverse, 5'-AATGTCCAGGAATTGCTCAAAC-3'; for $\alpha$ syn, forward, $5^{\prime}$-CACCATGGATGTATTCATGAAAGGAC-3', reverse, 5'-GGCTTCAGGTTCGTAGTCTTG-3'. The PCR products were then subcloned in-frame into the C-terminal V5-tagged expression vector pLenti6/V5-TOPO (Invitrogen) as described previously (Kitazawa et al., 2005; Latchoumycandane et al., 2005). A control lentiviral construct pLenti-V5-LacZ, encoding $\beta$-galactosidase fused to the V5 epitope, was also obtained from Invitrogen. To generate pGL3$\mathrm{PKC} \delta$ promoter construct, rat genomic DNA was isolated using the DNeasy Blood \& Tissue kit and used as template to amplify the $1.7 \mathrm{~kb}$ DNA fragment $(-1700$ to $+22,+1$ denotes the transcription start site) of rat PKC $\delta$ gene. PCR conditions used were $94^{\circ} \mathrm{C}$ for $45 \mathrm{~s} ; 30$ cycles of $94^{\circ} \mathrm{C}$ for $30 \mathrm{~s}, 64.6^{\circ} \mathrm{C}$ for $30 \mathrm{~s}$, and $72^{\circ} \mathrm{C}$ for $2 \mathrm{~min}$; and $72^{\circ} \mathrm{C}$ for $10 \mathrm{~min}$. After PCR, the amplified product was cloned into the XhoI/HindIII sites of pGL3-Basic vector (Promega). All constructs were verified by DNA sequencing.

Primary mesencephalic cultures and treatment. All of the procedures involving animal handling were approved by the Institutional Animal Care Use Committee (IACUC) at the Iowa State University. Primary mesencephalic neuronal cultures were prepared as described in our recent publications (Zhang et al., 2007a; Ghosh et al., 2010). Briefly, 24well plates containing coverslips were coated overnight with $0.1 \mathrm{mg} / \mathrm{ml}$ poly-D-lysine. Mesencephalon tissue was dissected from gestational 14d-old mouse embryos and kept in ice-cold $\mathrm{Ca}^{2+}$-free HBSS. Cells were then dissociated in HBSS containing trypsin-0.25\% EDTA for $30 \mathrm{~min}$ at $37^{\circ} \mathrm{C}$. After the incubation, $10 \%$ heat-inactivated fetal bovine serum in DMEM was added to inhibit trypsin digestion. The cells were triturated and suspended in Neurobasal medium supplemented with $2 \%$ Neurobasal supplement (B27), $500 \mu \mathrm{M} \mathrm{L}$-glutamine, $100 \mathrm{IU} / \mathrm{ml}$ penicillin, and $100 \mu \mathrm{g} / \mathrm{ml}$ streptomycin, plated at $1 \times 10^{6}$ cells in $0.5 \mathrm{ml} /$ well and incubated in a humidified $\mathrm{CO}_{2}$ incubator $\left(5 \% \mathrm{CO}_{2}\right.$ and $\left.37^{\circ} \mathrm{C}\right)$. One-half of the culture medium was replaced every $2 \mathrm{~d}$, and experiments were conducted using between 6 and $7 \mathrm{~d}$ cultures. After exposure to the NF $\kappa \mathrm{B}$ inhibitor SN-50 and the p300 inhibitor garcinol or the activator CTPB for $24 \mathrm{~h}$, the primary cultures were processed for immunocytochemical analysis.

Cell culture and stable expression of $\alpha$-synuclein. Rat immortalized mesencephalic dopaminergic neuronal cell line $\left(1 \mathrm{RB}_{3} \mathrm{AN}_{27}\right.$; referred to as N27 cells) was a kind gift from Dr. Kedar N. Prasad (University of Colorado Health Sciences Center, Denver, CO). Rat striatal GABAergic M213-20 cell line was a generous gift from Dr. William Freed (National Institute on Drug Abuse, National Institutes of Health, Baltimore, MD). Mouse dopaminergic MN9D cell line was a kind gift from Dr. Syed Ali (National Center for Toxicological Research/Food and Drug Administration, Jefferson, AR). Rat pheochromocytoma PC12 dopaminergic cell line and human dopaminergic neuroblastoma SH-SY5Y cell line were obtained from the American Type Culture Collection. N27 and PC12 cells were cultured as described previously (Zhang et al., 2007a). M21320, MN9D, and SH-SY5Y cells were grown in DMEM supplemented with $10 \%$ fetal bovine serum, $2 \mathrm{~mm}$ L-glutamine, $50 \mathrm{U}$ of penicillin, and $50 \mathrm{U}$ of streptomycin.

To generate a stable cell line expressing the human wild-type $\alpha$ syn, N27 cells were stably transfected with pCEP4- $\alpha$ syn or pCEP4 empty vector by Lipofectamine Plus reagent according to the procedure recommended by the manufacturer and described previously (Kaul et al., 2005b). The stable transfectants were selected in $400 \mu \mathrm{g} / \mathrm{ml}$ hygromycin and further maintained in $200 \mu \mathrm{g} / \mathrm{ml}$ hygromycin added to N27 growth media.

Animals. Transgenic mice (stock number 008389) that express human wild-type $\alpha$ syn under the control of the Thy-1 promoter (Andrä et al., 1996) and noncarrier littermate control mice were purchased from The Jackson Laboratory. This line of transgenic animals has been characterized previously (Chandra et al., 2005). It expresses high levels of $\alpha$ syn throughout the brain, but unlike some mutant transgenic lines, it does not display the Parkinson's-like phenotype. Six- to 8-week-old male transgenic and noncarrier control mice were housed in standard conditions: constant temperature $\left(22 \pm 1^{\circ} \mathrm{C}\right)$, humidity (relative, $\left.30 \%\right)$, and a 
$12 \mathrm{~h} \mathrm{light/dark} \mathrm{cycle} \mathrm{with} \mathrm{ad} \mathrm{libitum} \mathrm{access} \mathrm{to} \mathrm{food} \mathrm{and} \mathrm{water.} \mathrm{Animal}$ care procedures strictly followed the National Institutes of Health Guide for the Care and Use of Laboratory Animals and were approved by the Iowa State University IACUC.

Immunoblotting and immunoprecipitation. Cell lysates were prepared as described previously (Zhang et al., 2007a). Nuclear and cytoplasmic extracts were isolated using the NE-PER nuclear and cytoplasmic extraction kit (Thermo Fisher Scientific). The protein concentrations were determined with the Bradford protein assay kit at $595 \mathrm{~nm}$. Immunoblotting and densitometric analysis of immunoblots were performed as described previously (Kanthasamy et al., 2006). Briefly, the indicated protein lysates containing equal amounts of protein were fractionated through a $7.5-15 \%$ SDS-polyacrylamide gel and transferred onto a nitrocellulose membrane (Bio-Rad Laboratories). Membranes were blotted with the appropriate primary antibody and developed with HRPconjugated secondary antibody followed by ECL detection. IRDye800 anti-rabbit or Alexa 680-conjugated anti-mouse antibodies were also used as secondary antibodies. The immunoblot imaging was performed with either a Kodak image station IS2000MM (Kodak Molecular Imaging System) or an Odyssey infrared imaging system (LI-COR), and data were analyzed using one-dimensional image analysis software (Kodak Molecular Imaging System) or Odyssey software 2.0 (LI-COR). Blots were stripped and reprobed with anti- $\beta$-actin antibody as an internal control for loading.

For immunoprecipitation studies, briefly, cells were lysed in immunoprecipitation buffer (50 mм Tris- $\mathrm{HCl}, \mathrm{pH} 7.4,150 \mathrm{~mm} \mathrm{NaCl}, 1 \mathrm{~mm}$ EDTA, $10 \mathrm{~mm} \mathrm{NaF}, 1 \%$ Triton X-100, $1 \times$ halt protease inhibitor mixtures), and the resultant lysates were incubated on ice for $15 \mathrm{~min}$ followed by centrifugation at $16,000 \times g$ for $15 \mathrm{~min}$. The supernatant fractions were then precleared with protein $\mathrm{A}$ or protein $\mathrm{G}$ beads for $30 \mathrm{~min}$ at $4^{\circ} \mathrm{C}$ followed by centrifugation at $16,000 \times g$ at $4^{\circ} \mathrm{C}$ for $10 \mathrm{~min}$. Five micrograms of the indicated antibody along with $50 \mu \mathrm{l}$ of $50 \%$ of protein A or protein $\mathrm{G}$ beads were added to the cell lysates and incubated overnight at $4^{\circ} \mathrm{C}$ on a rotator. The immunoprecipitates were collected, washed extensively with cold PBS, and prepared for SDS-PAGE gel by addition of $2 \times$ SDS sample buffer and then boiling for $10 \mathrm{~min}$.

Transfections and infections. Transient transfections of $\alpha$ synexpressing and vector control N27 cells with promoter reporter were performed using Lipofectamine 2000 reagent in accordance with the manufacturer's protocol. Cells were plated in six-well plates at $4 \times 10^{5}$ cells/well $1 \mathrm{~d}$ before transfection. Four micrograms of pGL3-PKC $\delta$ construct or pGL3-Basic empty vector was transiently transfected, and $0.5 \mu \mathrm{g}$ of $\beta$-galactosidase vector (pcDNA3.1- $\beta$ gal; Invitrogen) was added to each well to monitor transfection efficiencies. Twenty-four hours after transfection, the cells were lysed in $200 \mu \mathrm{l}$ of Reporter lysis buffer (Promega). Luciferase activity was measured on a luminometer (Reporter Microplate; Turner Designs) using the Luciferase assay kit (Promega), and $\beta$-galactosidase activity was detected using the $\beta$-galactosidase assay kit (Promega). The ratio of luciferase activity to $\beta$-galactosidase activity was used as a measure of normalized luciferase activity.

Electroporation of siRNAs was conducted by using a Nucleofector device and the Cell Line Nucleofector kit (all from Lonza) following the manufacturer's instructions. Specific $\alpha$ syn siRNA (no. 16708) and scrambled negative control siRNA (no. 4611) were purchased from Ambion. The p300-specific siRNA (no. SI02989693) was purchased from QIAGEN. The NF $\kappa$ B-p65-specific siRNA as described (Chen et al., 2006) was synthesized by Integrated DNA Technologies. The siRNA sequence for $\alpha$ syn is $5^{\prime}$-GCAGGAAAGACAAAAGAGGtt- $3^{\prime}$ and for NF $\kappa \mathrm{B}-\mathrm{p} 65$ is 5'-GCAGUUCGAUGCUGAUGAAUU- 3 '. In each electroporation, $2 \times$ $10^{6}$ cells were resuspended in $100 \mu \mathrm{l}$ of the electroporation buffer supplied with the kit, along with $1.3 \mu \mathrm{g}$ of gene-specific siRNA or scrambled negative siRNA. The sample was then electroporated using the preset nucleofector program no. A23 recommended by the manufacturer. After electroporation, the cells were immediately transferred to prewarmed culture medium. The next day, media were replaced to normal growth media. Mock transfection with electroporation buffer alone was also included as a transfection control. After 72 or $96 \mathrm{~h}$ from the initial transfection, the cell lysates were collected and analyzed using Western blotting to confirm the extent of $\alpha$ syn, NF $\kappa$ B-p65, p300, and $\mathrm{PKC} \delta$ expression. Where indicated, the cell nuclear extracts were prepared and used for electrophoretic mobility shift assay (EMSA) analysis.

Lentiviral constructs (pLenti-V5-PKC $\delta$, pLenti-V5- $\alpha$ syn, or control construct pLenti-V5-LacZ) were packaged into virus via transient transfection of the 293FT packaging cell line (Invitrogen) using Lipofectamine 2000 reagent, as described previously (Cooper et al., 2006). The lentivirus in the medium was collected by centrifuging at $72-96 \mathrm{~h}$ after transfection. All transductions were performed at a multiplicity of infection of 1 in the presence of polybrene $(6 \mu \mathrm{g} / \mathrm{ml})$. To assess the effect of transient human $\alpha$ syn overexpression on PKC $\delta$ expression, N27 cells were infected with lentiviral particles encoding V5- $\alpha$ syn or V5-LacZ for $48 \mathrm{~h}$ and collected for immunoblot analysis. To test the effects of restoring PKC $\delta$ expression on $\mathrm{MPP}^{+}$neurotoxicity, stable $\alpha$ syn-expressing and vector control N27 cells were infected with PKC $\delta$ or control LacZ lentivirus for $24 \mathrm{~h}$. The cells were then treated with fresh media containing $300 \mu \mathrm{M} \mathrm{MPP}{ }^{+}$for $48 \mathrm{~h}$ before analysis. In experiments aimed at detecting the expression of pLenti-V5-PKC $\delta$ and pLenti-V5-LacZ, the cells were incubated with lentivirus for $48 \mathrm{~h}$ and collected for immunoblot analysis.

Caspase- 3 activity and DNA fragmentation assays. Caspase- 3 activity was measured as previously described (Kaul et al., 2005b). Briefly, after treatment with $300 \mu \mathrm{M} \mathrm{MPP}{ }^{+}$, cell lysates were prepared and incubated with a specific fluorescent substrate, Ac-DEVD-AMC $(50 \mu \mathrm{M})$, at $37^{\circ} \mathrm{C}$ for $1 \mathrm{~h}$. Caspase- 3 activity was then measured using a SpectraMax Gemini XS Microplate Reader (Molecular Devices) with excitation at $380 \mathrm{~nm}$ and emission at $460 \mathrm{~nm}$. The caspase- 3 activity was calculated as fluorescence units per milligram of protein.

DNA fragmentation assay was performed using a Cell Death Detection ELISA Plus kit as previously described (Anantharam et al., 2002). Briefly, after treatment with $300 \mu \mathrm{M} \mathrm{MPP}{ }^{+}$, cells were collected and lysed in 450 $\mu \mathrm{l}$ of lysis buffer supplied with the kit for $30 \mathrm{~min}$ at room temperature, and spun down at $2300 \times g$ for $10 \mathrm{~min}$ to collect the supernatant. The supernatant was then used to measure DNA fragmentation as per the manufacturer's protocol. Measurements were made at 405 and $490 \mathrm{~nm}$ using a SpectraMax 190 spectrophotometer (Molecular Devices).

Immunostaining and microscopy. After perfusion with $4 \%$ paraformaldehyde, the mice brains were removed, immersion fixed in $4 \%$ paraformaldehyde, and cryoprotected in sucrose. Then the brain was cut on a microtome into $20 \mu \mathrm{m}$ sections. Sections from substantia nigra were used for dual-labeled immunofluorescence. After washing with PBS, the brain sections were rinsed with blocking buffer containing $2 \%$ BSA, $0.05 \%$ Tween 20, and $0.5 \%$ Triton X-100 in PBS for 45 min, and then incubated overnight at $4^{\circ} \mathrm{C}$ with the following combinations of primary antibodies: anti-PKC $\delta$ (1:250; Santa Cruz) and anti-TH (1:1800; Millipore Bioscience Research Reagents), or anti-p300 (1:350; Santa Cruz) and anti-TH (1:1800; Millipore Bioscience Research Reagents), followed by incubation with anti-rabbit Alexa 568-conjugated (red; 1:1000) and anti-mouse Alexa 488-conjuated secondary antibodies (green; 1:1000) for $1 \mathrm{~h}$ at room temperature. After this, Hoechst $33342(10 \mu \mathrm{g} / \mathrm{ml})$ was added for $3 \mathrm{~min}$ at room temperature to stain the nucleus. The brain sections were mounted and observed with either an oil-immersion $63 \times$ PL APO lens with a 1.40 numerical aperture or an oil-immersion $100 \times$ PL APO lens with a 1.40 numerical aperture using a Leica SP5 X confocal microscope system (all from Leica) at the Confocal Microscopy and Image Analysis Facility at Iowa State University. For final output, images were processed using LAS-AFlite software (Leica). For computer-assisted image analysis, a $0.051 \mathrm{~mm}^{2}$ area was delineated using this LAS-AFlite software and TH-PKC $\delta$ colocalized dopaminergic neurons were counted independently and blindly by two investigators. Data were expressed as either percentage of TH-positive cells containing PKC $\delta$ immunoreactivity/total TH neurons or number of TH-positive cells containing PKC $\delta$ immunoreactivity/area (in square millimeters).

Immunostaining of $\mathrm{PKC} \delta$, $\mathrm{TH}$, and $\alpha$ syn was performed in primary mesencephalic neurons, $\alpha$ syn-expressing and vector control N27 cells. Cells grown on coverslips precoated with poly-L-lysine or poly-D-lysine were washed with PBS and fixed in 4\% paraformaldehyde for $30 \mathrm{~min}$. After washing, the cells were permeabilized with $0.2 \%$ Triton X-100 in PBS, washed with PBS, and blocked with blocking agent (5\% bovine serum albumin, $5 \%$ goat serum in PBS). Cells were then incubated with the antibody against human $\alpha$ syn (1:500; Santa Cruz), TH (1:1800; Mil- 
lipore Bioscience Research Reagents), and PKC $\delta$ (1:1000; Santa Cruz) overnight. Fluorescently conjugated secondary antibody (Alexa 488conjugated anti-mouse antibody, green, 1:1500; or Alexa 568-conjugated anti-rabbit antibody, red, 1:1500) was used to visualize the protein. $\mathrm{Nu}-$ clei were counterstained with Hoechst 33342 for 3 min at a final concentration of $10 \mu \mathrm{g} / \mathrm{ml}$. Finally, images were viewed using an oil-immersion $60 \times$ PL Apo lens with a 1.45 numerical aperture on a Nikon inverted fluorescence microscope (model TE2000; Nikon). Images were captured with a SPOT color digital camera (Diagnostic Instruments) and processed using MetaMorph 5.07 image analysis software (Molecular Devices). For quantitative analysis of immunofluorescence, we measured average pixel intensities from the region of interest using the MetaMorph 5.07 image analysis software.

Pulse-chase assays. Before pulse labeling, cells were starved of methionine for $30 \mathrm{~min}$. Cells were subsequently pulse-labeled with methioninefree RPMI 1640 medium containing $125 \mu \mathrm{Ci} / \mathrm{ml}\left[{ }^{35} \mathrm{~S}\right]$ methionine for $2 \mathrm{~h}$. Afterward, cells were rinsed twice with warm PBS and chased in complete growth medium for various times up to $48 \mathrm{~h}$. At different chase times, the cells were collected and subsequently subjected to immunoprecipitation using PKC $\delta$ antibody as described above. The immunoprecipitates were separated with $10 \%$ SDS-PAGE and analyzed by autoradiography at $24-48 \mathrm{~h}$ using a PhosphoImager (Personal Molecular Imager FX; Bio-Rad Laboratories). Band quantifications were processed using Quantity One 4.2.0 software (Bio-Rad Laboratories).

Reverse transcription-PCR and methylation-specific PCR. Total RNA was isolated and converted to cDNA using Absolutely RNA Miniprep kit from Stratagene and High Capacity cDNA Archive kit from Applied Biosystems, respectively. For semiquantitative reverse transcription (RT)-PCR, $1 \mu$ l of the reverse transcriptase reaction mixture served as a template in PCR amplification. PCR amplifications were performed using the following program: $94^{\circ} \mathrm{C}$ for $3 \mathrm{~min} ; 35$ cycles of $94^{\circ} \mathrm{C}$ for $45 \mathrm{~s}, 56^{\circ} \mathrm{C}(\mathrm{PKC} \delta, \eta$, and $\lambda)$ or $60^{\circ} \mathrm{C}(\mathrm{PKC} \alpha, \varepsilon, \zeta$, and $\mathrm{GAPDH}$ ) for $30 \mathrm{~s}, 72^{\circ} \mathrm{C}$ for $45 \mathrm{~s}$. PCR products were then separated by electrophoresis in 1-2\% agarose gel and visualized by ethidium bromide staining.

Quantitative real-time RT-PCR was performed using Brilliant SYBR Green QPCR Master Mix kit and the Mx3000P QPCR system (all from Stratagene). The $\mathrm{p} 300$ primer set was using a QuantiTect Primers assay (QIAGEN; QT01083859). The $\beta$-actin was used as an internal control for RNA quantity (sequence is listed in supplemental Table 1, available at www.jneurosci.org as supplemental material). The reaction mixture included $1 \mu \mathrm{l}$ of cDNA (100 ng of RNA used), $12.5 \mu \mathrm{l}$ of $2 \times$ master mix, $0.375 \mu \mathrm{l}$ of reference dye, and $0.2 \mu \mathrm{M}$ each primer. Cycling conditions contained an initial denaturation at $95^{\circ} \mathrm{C}$ for $10 \mathrm{~min}$, followed by 40 cycles of $95^{\circ} \mathrm{C}$ for $30 \mathrm{~s}, 60^{\circ} \mathrm{C}$ for $30 \mathrm{~s}$, and $72^{\circ} \mathrm{C}$ for $30 \mathrm{~s}$. Fluorescence was detected during the annealing/extension step of each cycle. Dissociation curves were run to verify the singularity of the PCR product. The data were analyzed using the comparative threshold cycle method. Briefly, the relative PKC $\delta$ expression (expressed as fold differences) between $\alpha$ syn-expressing and vector control N27 cells was calculated as $2^{-(\Delta \mathrm{CtSYN}-\Delta \mathrm{CtVEC})}$, where $\Delta \mathrm{Ct}$ represented the mean $\mathrm{Ct}$ value of $\mathrm{PKC} \delta$ or $\mathrm{p} 300$ after normalization to $\beta$-actin internal control.

For methylation-specific PCR (MSP) experiments, genomic DNA was isolated from $\alpha$ syn-expressing and vector control N27 cells using the DNeasy Blood \& Tissue kit as mentioned earlier. Bisulfite modification was subsequently performed on $500 \mathrm{ng}$ of genomic DNA by the MethylDetector bisulfite modification kit (Active Motif) according to the manufacturer's instructions. Two pairs of primers were designed to amplify specifically methylated or unmethylated $\mathrm{PKC} \delta$ sequence using MethPrimer software (Li and Dahiya, 2002). The cycling condition was as follows: $94^{\circ} \mathrm{C}$ for $3 \mathrm{~min}$, after which 35 cycles of $94^{\circ} \mathrm{C}$ for $30 \mathrm{~s}, 52.5^{\circ} \mathrm{C}$ for $30 \mathrm{~s}, 68^{\circ} \mathrm{C}$ for $30 \mathrm{~s}$, and finally $72^{\circ} \mathrm{C}$ for $5 \mathrm{~min}$. PCR products were loaded onto $2 \%$ agarose gels for analysis. Negative control PCRs were performed using water only as template.

Assessments of mRNA stability. The PKC $\delta$ mRNA decay experiments were conducted as described previously (Jing et al., 2005) with some modification. Briefly, cells were treated with $5 \mu \mathrm{g} / \mathrm{ml}$ actinomycin D to block de novo transcription, total RNA were isolated at selected time points thereafter, and the amount of PKC $\delta$ mRNA was determined by quantitative real-time RT-PCR. The PKC $\delta$ mRNA values were normalized to the amount of $\beta$-actin internal control in each sample and expressed as the percentage of mRNA levels present at time 0 (set to $100 \%$ ) before the addition of actinomycin D.

Nuclear run-on assays. The nuclear run-on assays were performed with minor modifications to the method described by Patrone et al. (2000). Nuclei were prepared from $60 \times 10^{6}$ cells by resuspending in $4 \mathrm{ml}$ of Nonidet P-40 lysis buffer (10 mm Tris- $\mathrm{HCl}, \mathrm{pH}$ 7.4, 3 mM $\mathrm{MgCl}_{2}, 10 \mathrm{~mm}$ $\mathrm{NaCl}, 150 \mathrm{~mm}$ sucrose, and $0.5 \%$ Nonidet $\mathrm{P}-40$ ), and a 5 min incubation in ice followed. Nuclei were isolated by centrifugation, washed with cell lysis buffer devoid of Nonidet P-40, and the pellets were resuspended in $100 \mu \mathrm{l}$ of freezing buffer (50 mM Tris- $\mathrm{HCl}, \mathrm{pH} 8.3,40 \%$ glycerol, $5 \mathrm{~mm}$ $\mathrm{MgCl}_{2}$, and $0.1 \mathrm{~mm}$ EDTA). One volume of transcription buffer $(200 \mathrm{~mm}$ $\mathrm{KCl}, 20 \mathrm{~mm}$ Tris- $\mathrm{HCl}, \mathrm{pH} 8.0,5 \mathrm{~mm} \mathrm{MgCl}_{2}, 4 \mathrm{~mm}$ dithiothreitol, 4 mM each of ATP, GTP, and CTP, 200 mm sucrose, and 20\% glycerol) was added to nuclei. Eight microliters of biotin-16-UTP was then supplied to the mixture. After incubation for $30 \mathrm{~min}$ at $29^{\circ} \mathrm{C}$, the reaction was terminated and total RNA was purified using the Absolutely RNA Miniprep kit according to the manufacturer's instructions. RNA was eluted in $60 \mu \mathrm{l}$ of nuclease-free water and $10 \mu \mathrm{l}$ was saved as total nuclear RNA. Dynabeads M-280 (50 $\mu \mathrm{l})$ was subsequently used to capture the run-on RNA. Three microliters of run-on RNA or $10 \mu \mathrm{g}$ of total nuclear RNA was subjected to cDNA synthesis and quantitative real-time PCR as described above. To monitor undesired RNA capture by Dynabeads, control reactions were also performed in which conditions were identical except that UTP was added to the transcription system in the place of biotin-16-UTP.

EMSAs. Nuclear and cytoplasmic proteins were prepared using the NE-PER nuclear and cytoplasmic extraction kit as described before. The IRye700-labeled oligos Pkc $\delta \mathrm{NF} \kappa \mathrm{Bs}$ and $\mathrm{NF} \kappa \mathrm{B}$, corresponding to the $\mathrm{NF} \kappa \mathrm{B}$-like sequences within the rat $\mathrm{PKC} \delta$ promoter and the consensus sequence of $\mathrm{NF} \kappa \mathrm{B}$, respectively, were synthesized by LI-COR and used as labeled probes. The unlabeled competitor oligos were obtained from Integrated DNA Technologies. All oligos sequences are illustrated in supplemental Table 2 (available at www.jneurosci.org as supplemental material). Protein-DNA binding reactions were performed with 5-10 $\mu \mathrm{g}$ of nuclear proteins, $1 \mu \mathrm{l}$ of labeled oligonucleotide $(50 \mathrm{fmol})$ in a total volume of $20 \mu \mathrm{l}$ of mixture containing $10 \mathrm{~mm}$ Tris- $\mathrm{HCl}, \mathrm{pH} 7.5,50 \mathrm{~mm}$ $\mathrm{NaCl}, 0.25 \%$ Tween 20, $2.5 \mathrm{~mm}$ DTT, $0.05 \mathrm{~mm}$ EDTA, and $1 \mu \mathrm{g}$ of poly (dI-dC). After incubation at room temperature for $20 \mathrm{~min}$, the resulting DNA-protein complexes were resolved on a $6.6 \%$ nondenaturing polyacrylamide gel at $10 \mathrm{~V} / \mathrm{cm}$ for $\sim 50 \mathrm{~min}$ at $4^{\circ} \mathrm{C}$ in $1 \times \mathrm{TGE}$ buffer. Gels were analyzed on the Odyssey infrared imaging system (LICOR). In competition experiments, before the addition of the labeled probe, nuclear extracts were preincubated for $30 \mathrm{~min}$ at room temperature with a 100-fold molar excess of unlabeled competitor oligos. In supershift experiments, 400 ng of anti-p50, anti-p65, or normal rabbit IgG was incubated with nuclear extracts for $30 \mathrm{~min}$ at room temperature before the addition of labeled probe.

Histone acetyltransferase activity assays. p300 histone acetyltransferase (HAT) activity was measured using a p300/CBP immunoprecipitation HAT assay kit from Millipore following the manufacturer's protocol with minor modifications as previously described (Nakatani et al., 2003). Briefly, one milligram of nuclear extracts from $\alpha$ syn-expressing and vector control N27 cells were precipitated with $5 \mu \mathrm{g}$ of anti-p300 antibody or normal mouse IgG and $50 \mu \mathrm{l}$ of magnetic protein-G beads (Active Motif) at $4^{\circ} \mathrm{C}$ overnight. The collected beads were washed with three times cold PBS and incubated with HAT assay mixture $(50 \mu \mathrm{l})$ containing $10 \mu \mathrm{l}$ of core histones and $100 \mu \mathrm{M}\left[{ }^{3} \mathrm{H}\right]$ acetyl-CoA $(0.5 \mu \mathrm{Ci} / \mu \mathrm{l})$ at $30^{\circ} \mathrm{C}$ for 30 min. Fifteen microliters of the supernatant of each sample was placed on P81 square papers and $\left[{ }^{3} \mathrm{H}\right]$ acetyl incorporation into the substrates was measured using a scintillation counter. Data were expressed as mean values of counts, subtracted from background values measured in samples containing normal mouse IgG.

Chromatin immunoprecipitation assays. The ChIP-IT Express enzymatic kit from Active Motif was used to analyze the in vivo binding of $\mathrm{NF} \kappa \mathrm{B}$ p 65 and p50 subunits, and p300/CBP coactivators onto the rat $\mathrm{PKC} \delta$ promoter region. Unless otherwise stated, all reagents, buffers, and supplies were included in the kit. The chromatin immunoprecipitation (ChIP) assays were performed following the manufacturer's instructions 
with slight modifications. Briefly, $\sim 1.5 \times 10^{7}$ cells were fixed in $1 \%$ formaldehyde for $10 \mathrm{~min}$ at room temperature. After cross-linking, the nuclei were prepared and chromatin was enzymatic digested to $200-$ $1500 \mathrm{bp}$ fragments (verified through running on a $1 \%$ agarose gel) by incubation with the enzymatic shearing mixture for $12 \mathrm{~min}$ at $37^{\circ} \mathrm{C}$. The sheared chromatin was collected by centrifuge, and a $10 \mu \mathrm{l}$ aliquot was saved as an input sample. Aliquots of $70 \mu \mathrm{l}$ of sheared chromatin were incubated overnight with rotation at $4^{\circ} \mathrm{C}$ with protein $\mathrm{G}$ magnetic beads and $3 \mu \mathrm{g}$ of indicated antibody. Equal aliquots of each chromatin sample were saved for no-antibody controls. After extensive washing, reversal of cross-links, and proteinase K digestion, the elute DNA in the immunoprecipitated samples was directly collected on a magnetic stand, and the input DNA was purified by phenol/chloroform extraction and ethanol precipitation. The DNA samples were analyzed by PCR using primer pairs designed to amplify a region $(-103$ to +60$)$ within $\mathrm{PKC} \delta$ promoter. Conditions of linear amplification were determined empirically for the primers. PCR conditions were as follows: $94^{\circ} \mathrm{C}$ for $3 \mathrm{~min} ; 94^{\circ} \mathrm{C}$ for $20 \mathrm{~s}, 58^{\circ} \mathrm{C}$ for $30 \mathrm{~s}$, and $72^{\circ} \mathrm{C}$ for $30 \mathrm{~s}$ for 35 cycles. The PCR products were resolved by electrophoresis in a $1.0 \%$ agarose gel and visualized after ethidium bromide staining.

Bioinformatics. CpG island identification was analyzed with the webbased program CpG Island Searcher (Takai and Jones, 2002). This program defines a $\mathrm{CpG}$ island as a region with a $\mathrm{G}+\mathrm{C}$ content $\geq 50 \%$, longer than $200 \mathrm{bp}$ nucleotides, and an observation/expectation CpG ratio $>0.6$. The search for the phylogenetic sequence conservation among rat, human, murine, and cow $\mathrm{PKC} \delta$ promoter was conducted with the DiAlign Professional TF release 3.1.1 (DiAlign TF) (Morgenstern et al., 1996, 1998) (Genomatix Software). This program identifies common transcription factor binding site matches located in aligned regions through a combination of alignment of input sequences using multiple alignment program DiAlign (Morgenstern et al., 1996, 1998) with recognition of potential transcriptional factor binding sites by MatInspector software (Cartharius et al., 2005) (Genomatix Software), which used matrices library, version 8.0.

Data analysis. All statistical analyses were performed using the Prism 4.0 software (GraphPad Software). In PKC $\delta$ protein and mRNA degradation experiments, a one-phase exponential decay model was fitted to each data set using the nonlinear regression analysis program of Prism 4.0 software as follows: $Y=\operatorname{span} e^{-K t}+$ plateau, where $Y$ starts at span + plateau and decays with a rate constant $K$. The half-life of the each mRNA or protein was subsequently determined by $0.693 / K$. The goodness-of-fit was assessed as the square of the correlation coefficient $\left(R^{2}\right)$. Data were analyzed either by Student's $t$ test or one-way ANOVA followed by Tukey's pairwise multiple-comparison test. Statistical significance was defined as $p<0.05$.

\section{Results}

\section{Expression of human $\alpha$-synuclein in N27 dopaminergic cells downregulates PKC $\boldsymbol{\delta}$ expression in an isoform-specific manner}

We previously reported that $\mathrm{PKC} \delta$ serves as a key proapoptotic effector in dopaminergic neurons, and caspase-3-mediated proteolytic cleavage of PKC $\delta$ is a key mediator in multiple models of dopaminergic neurodegeneration (Anantharam et al., 2002; Kaul et al., 2003, 2005a; Yang et al., 2004; Kanthasamy et al., 2006; Zhang et al., 2007b). Growing evidence indicates that the neuroprotective mechanism of endogenous $\alpha$ syn involves deregulation of gene expression of specific stress-signaling molecules linked to neuronal survival (Alves Da Costa et al., 2002; Hashimoto et al., 2002; Manning-Bog et al., 2003; Albani et al., 2004). Analysis in a variety of cell lines, MN9D, N27, PC12, M213-20, and SH-SY5Y, revealed a striking inverse correlation between PKC $\delta$ and $\alpha$ syn protein levels (data not shown). These observations raised the question of whether $\alpha$ syn might regulate PKC $\delta$ expression and thereby promote cell survival. To address this hypothesis, we engineered rat-immortalized mesencephalic dopaminergic N27 cell line to express human wild-type $\alpha$ syn by stably transfecting with plasmid pCEP4- $\alpha$ syn or pCEP4 control vector. The widely used N27 neuronal cell model represents a homogeneous population of TH-positive dopaminergic cells and is highly useful for studying degenerative mechanisms in PD (Clarkson et al., 1999; Kaul et al., 2005a; J. Peng et al., 2005; Zafar et al., 2007; Zhang et al., 2007a; Lee et al., 2009). The stable expression of human $\alpha$ syn in stable N27 cells was assessed by Western blot assay using the $\alpha$ syn antibody (Syn-1) that detects both exogenously expressed human $\alpha$ syn and endogenous rat $\alpha$ syn. As shown in Figure $1 A$, the $\alpha$ syn endogenous level was too low to be detected in vector control N27 cells, whereas exogenously expressed $\alpha$ syn could readily be detected in the $\alpha$ syn-expressing N27 cells. Importantly, the level of $\alpha$ syn achieved in $\alpha$ syn-expressing N27 cells appears to be within the physiological range, as this level was comparable with that seen in the rat brain substantia nigra (rSN) homogenates (Fig. 1A). Additional analysis of subcellular localization of $\alpha$ syn in the stable cells demonstrated that $\alpha$ syn is exclusively in the cytoplasm but absent in the nucleus (supplemental Fig. 1, available at www.jneurosci.org as supplemental material). We next determined whether $\alpha$ syn affects PKC $\delta$ expression. Western blot analysis (Fig. $1 B$, left panel) of various PKC isoforms showed a selective suppression of PKC $\delta$ in $\alpha$ syn-expressing N27 cells. Quantitative analysis showed that $\alpha$ syn caused a $\sim 50 \%$ reduction in PKC $\delta$ protein levels, whereas $\mathrm{PKC} \alpha, \beta \mathrm{I}$, and $\zeta$ were not affected (Fig. $1 B$, right panel). To further determine whether this specific inhibition occurred at the mRNA level, semiquantitative RT-PCR (primer sequences are listed in supplemental Table 1, available at www.jneurosci.org as supplemental material) was performed (Fig. $1 C$, left panel). Similar to the trend seen in protein levels, only PKC $\delta$ mRNA expression was markedly reduced by $\alpha$ syn. Quantitative RT (qRT)-PCR analysis revealed a dramatic $\sim 80 \%$ reduction in PKC $\delta$ mRNA in $\alpha$ syn-expressing N27 cells (Fig. $1 C$, right panel). To ensure the observed downregulation of $\mathrm{PKC} \delta$ gene expression in these two stable cell lines was not an artifact from the selection or maintenance of stable transfectants, we examined the $\mathrm{PKC} \delta$ expression in transiently transduced N27 cells. As shown in Figure 1D, transient transduction of N27 cells with lentivirus encoding human wild-type $\alpha$ syn-V5 fusion also resulted in a dramatic decrease in expression of PKC $\delta$ gene compared with control lentivirus (lacZV5)-infected cells. Together, these data demonstrate that $\alpha$ syn is capable of repressing the $\mathrm{PKC} \delta$ isoform in N27 dopaminergic cells.

\section{Dysregulation of PKC $\delta$ by $\alpha$-synuclein protects against $\mathrm{MPP}^{+}$-induced cell death in dopaminergic N27 cells}

After we identified that increased $\alpha$ syn inhibits the steady-state level of PKC $\delta$, we investigated the significance of PKC $\delta$ downregulation by $\alpha$ syn. Previously, we established the proapoptotic function of PKC $\delta$ in dopaminergic neurons using siRNA and dominant-negative PKC $\delta$ mutants (Yang et al., 2004; Kitazawa et al., 2005; Latchoumycandane et al., 2005). In the present study, we used a lentivirus encoding $\mathrm{PKC} \delta$ fused to the V5 epitope $(\mathrm{PKC} \delta$-V5) to markedly overexpress $\mathrm{PKC} \delta$ and investigated whether PKC $\delta$ gain of function influences the neurotoxicity in $\mathrm{N} 27$ cells after $\mathrm{MPP}^{+}$treatment. The increased expression of $\mathrm{PKC} \delta$ after lentiviral infection compared with control lentivirusinfected cells (LacZ) was confirmed by Western blot assay (data not shown). The extent of $\mathrm{MPP}^{+}$-induced apoptosis was measured by DNA fragmentation (Fig. $2 A$, left panel) and caspase- 3 enzymatic activity (Fig. $2 A$, right panel) analysis. In LacZ control-infected cultures, $\alpha$ syn-expressing N27 cells almost completely suppressed $\mathrm{MPP}^{+}$-induced DNA fragmentation and 
A
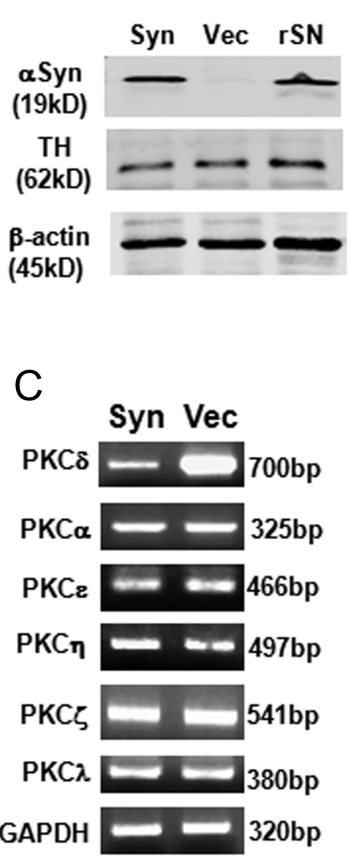

B
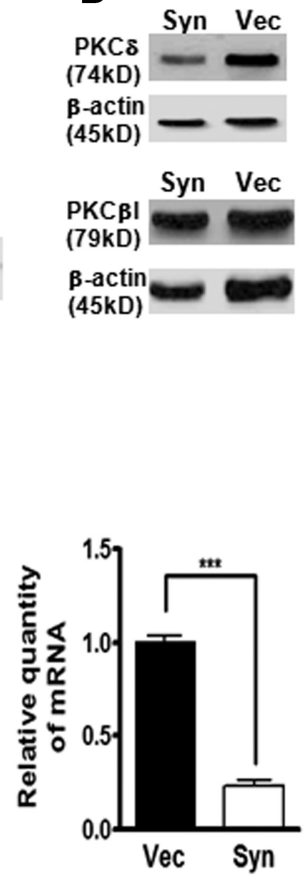
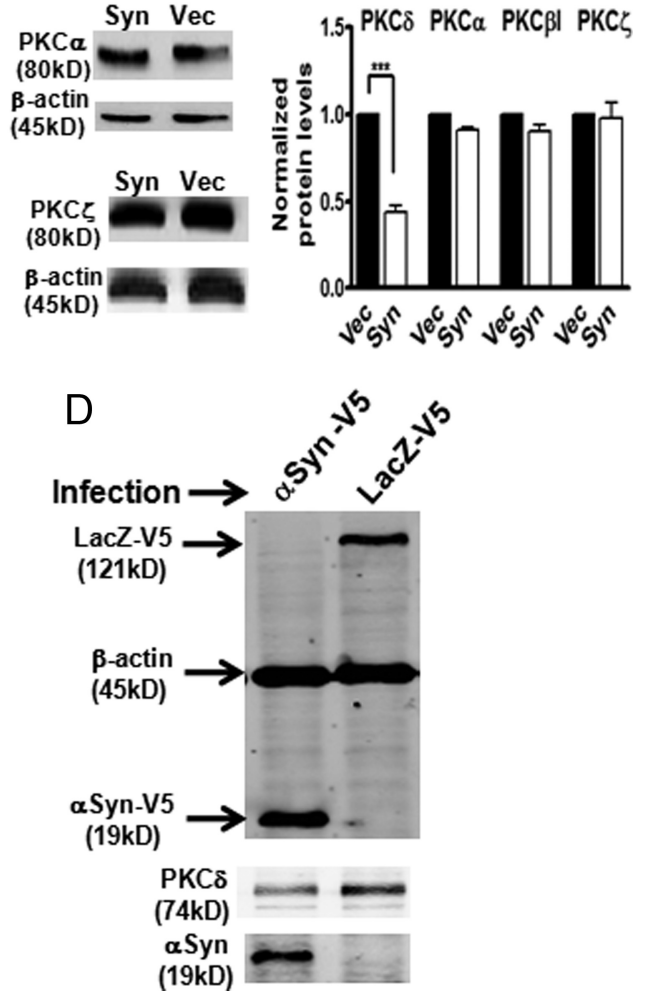

Figure 1. $\alpha$-Synuclein specifically downregulates PKC $\delta$ isoform in N27 dopaminergic cells. A, Whole-cell extracts from stably expressing $\alpha$ syn N27 cells (Syn), vector control N27 cells (Vec), and rat substantia nigra brain (rSN) were prepared. Expression of $\alpha$ syn and TH were determined by immunoblotting assay with antibodies against $\alpha$ syn (Syn-1; BD Biosciences) and TH. $\beta$-actin was used as a loading control. B, The specific downregulation of PKC $\delta$ protein in $\alpha$ syn-expressing N27 cells. Representative immunoblots (left panel) and quantitation (right panel) of PKC isoforms ( $\delta, \alpha, \beta$, and $\zeta)$ in whole-cell lysates in $\alpha$ syn-expressing (Syn) and vector control (Vec) N27 cells. Data shown are mean \pm SEM from three separate experiments ( $\left.{ }^{* * *} p<0.001\right)$. C, Left, Semiquantitative RT-PCR analysis of mRNA levels of various PKC isoforms. Amplicon base pairs are shown at the right sides of the panel. GAPDH was used as loading control. Right, $q R T-P C R$ analysis for PKC $\delta$ mRNA expression in $\alpha$ syn-expressing and vector control N27 cells. Data shown represent mean \pm SEM from four separate experiments performed in triplicate $\left({ }^{* * *} p<0.001\right)$. D, Transient overexpression of human wild-type $\alpha$ syn in N27 cells by lentiviral infection downregulates PKC $\delta$ protein expression. N27 cells were infected with lentiviruses expressing LacZ-V5 (control lentiviral vector) or $\alpha$ syn-V5 for $48 \mathrm{~h}$, and whole-cell lysates were analyzed for V5 and $\beta$-actin (top panel), PKC $\delta$ (middle panel), and $\alpha$ syn (bottom panel). A representative immunoblot is shown.

caspase-3 activity compared with vector control N27 cells. Importantly, introduction of $\mathrm{PKC} \delta$ significantly increased $\mathrm{MPP}^{+}{ }_{-}$ induced DNA fragmentation $(p<0.01)$ and caspase- 3 activity $(p<0.05)$ in $\alpha$ syn-expressing N27 cells. These results suggest that downregulation of $\mathrm{PKC} \delta$ by $\alpha$ syn is protective. In additional support of these data, $\mathrm{MPP}^{+}$-induced $\mathrm{PKC} \delta$ proteolytic cleavage and its nuclear translocation, events associated with apoptosis (Anantharam et al., 2002; DeVries et al., 2002; Kaul et al., 2003, 2005a), were almost completely diminished in $\alpha$ syn-expressing N27 cells compared with vector control N27 cells (Fig. 2 B).

Next, we examined the localization of $\alpha$ syn in the stable cells after $\mathrm{MPP}^{+}$treatment. As shown in Figure $2 C$, the exclusive localization of $\alpha$ syn in the cytoplasm was not affected by $\mathrm{MPP}^{+}$, as determined by Western blot and immunostaining. Interestingly, a recent study demonstrates that subcellular localization of $\alpha$ syn may contribute to its neurotoxicity: nuclear localization of $\alpha$ syn promotes apoptosis, whereas cytoplasmic localization of $\alpha$ syn protects cells (Kontopoulos et al., 2006). Together, these results support a model in which $\alpha$ syn acts in the cytoplasm to protect against $\mathrm{MPP}^{+}$-induced dopaminergic cell death via negative regulation of the proapoptotic kinase $\mathrm{PKC} \delta$ expression.

Increased $\boldsymbol{\alpha}$-synuclein expression in an animal model is associated with decreased PKC $\delta$ levels within nigral dopaminergic neurons

We further extend our findings from a dopaminergic cell culture model to an animal model. Since recent studies conducted in our laboratory demonstrated that $\mathrm{PKC} \delta$ is expressed in dopaminergic neurons in nigral regions of the brain (Zhang et al., 2007a), we decided to determine whether an inverse relationship between $\alpha$ syn and $\mathrm{PKC} \delta$ expression in nigral dopaminergic neurons existed in vivo. For this purpose, we performed immunohistological studies in transgenic mice that overexpress wild-type human $\alpha$ syn (htg) and in nontransgenic control (non-tg) mice. This transgenic line has been characterized previously (Chandra et al., 2005); it expresses high levels of $\alpha$ syn throughout the brain under the regulatory control of the Thy- 1 promoter, and unlike some similar mutant transgenic lines, it does not display the Parkinson'slike phenotype on aging. This mouse line also displayed a dramatic resistance to the neurodegeneration caused by deletion of cysteine-string protein- $\alpha(\mathrm{CSP} \alpha)($ Chandra et al., 2005). The effects of overexpression of $\alpha$ syn on PKC $\delta$ expression within nigral dopaminergic neurons were studied by double-immunostaining nigral tissues for $\mathrm{TH}$ (marker of dopaminergic neurons) and $\mathrm{PKC} \delta$. As shown in Figure $3 A$, a strong PKC $\delta$ immunoreactivity (stained in red) was observed in control mice in the cytoplasm of $\mathrm{TH}$-expressing neurons (stained in green). Moreover, the majority of the TH neurons displayed colocalization of TH and PKC $\delta$ (yellow color in the merged panel). In contrast, the $\alpha$ syntransgenic mice exhibited a significant decrease in PKC $\delta$ immunoreactivity within $\mathrm{TH}$ neurons as well as significant loss of the corresponding colocalization of $\mathrm{TH}$ and $\mathrm{PKC} \delta$. Quantitative analysis of $\mathrm{TH}-\mathrm{PKC} \delta$-colocalized dopaminergic neurons relative to the number of total $\mathrm{TH}$ neurons showed that $>70 \%$ of $\mathrm{TH}$ - 
A
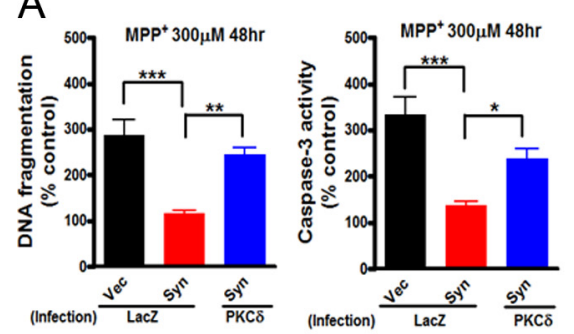

B

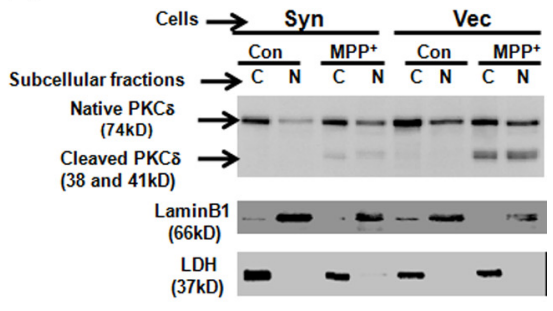

C

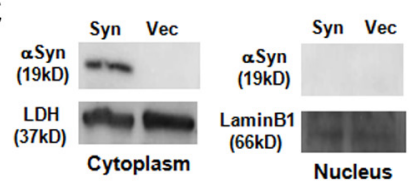

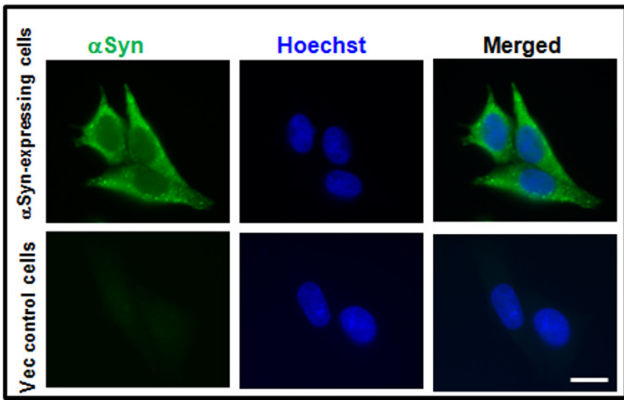

Figure 2. Deregulation of PKC $\delta$ by $\alpha$-synuclein protects against MPP ${ }^{+}$-induced cell death in dopaminergic $\mathrm{N} 27$ cells. $A$, Effects of downregulation of PKC $\delta$ by $\alpha$ syn on MPP ${ }^{+}$-induced cell death in dopaminergic N27 cells. $\alpha$ Syn-expressing (Syn) and vector control (Vec) N27 cells were infected with lentiviruses expressing LacZ-V5 or PKC $\delta$-V5 for $24 \mathrm{~h}$. The cells were then exposed to $\mathrm{MPP}^{+}(300 \mu \mathrm{M})$ for $48 \mathrm{~h}$. Cells were collected and assayed for DNA fragmentation (left panel) and caspase-3 activity (right panel). Data shown represent mean \pm SEM from two independent experiments performed in quadruplicate $\left({ }^{*} p<0.05\right.$; ${ }^{* *} p<0.01$; $\left.{ }^{* * *} p<0.001\right) \cdot B, \mathrm{MPP}^{+}$-induced PKC $\delta$ proteolytic cleavage and its nuclear translocation were significantly diminished in $\alpha$ syn-expressing N27 cells. $\alpha$ Syn-expressing (Syn) and vector control (Vec) N27 cells were exposed to MPP ${ }^{+}(300 \mu \mathrm{M})$ for $36 \mathrm{~h}$. Cytoplasmic (C) and nuclear (N) fractions were prepared for immunoblotting analysis of PKC $\delta$. LDH (cytoplasmic fraction) and Lamin B1 (nuclear fraction) were used as loading controls. C, Cytoplasmic localization of $\alpha$ syn in $\alpha$ syn-expressing N27 cells was not affected by MPP + ${ }^{+}$treatment. $\alpha$ Syn-expressing (Syn) and vector control (Vec) N27 cells were exposed to MPP ${ }^{+}$(300 $\mu \mathrm{M}$ ) for $36 \mathrm{~h}$. Cells were either collected for preparation of cytoplasmic and nuclear extracts and immunoblotting analysis of $\alpha$ syn (left panel) or stained and visualized under a Nikon TE2000 fluorescence microscope (right panel). Scale bar, $10 \mu \mathrm{m}$. A representative immunoblot and image of $\alpha$ syn immunostaining (green) and Hoechst staining (blue) are shown. tified PKC $\delta$ mRNA by qRT-PCR (Fig. $4 B)$. The relative half-life of PKC $\delta$ mRNA was $\sim 2 \mathrm{~h}$ in vector control cells, and the decay continued thereafter. Notably, overexpression of $\alpha$ syn did not change the relative half-life of PKC $\delta$ mRNA (degradation rate $K=0.396 \pm 0.039$ per hour in vector cells vs $0.415 \pm 0.058$ per hour in $\alpha$ syn-expressing cells). Together, these results demonstrate that $\alpha$ syn-induced suppression of $\mathrm{PKC} \delta$ is not attributable to altered rate of $\mathrm{PKC} \delta$ protein or mRNA decay, suggesting that there are no posttranscriptional effects of $\alpha$ syn on PKC $\delta$ expression.

We therefore turned our attention to transcriptional steps that could mediate the reduction in $\mathrm{PKC} \delta$ via $\alpha$ syn. We first examined whether $\alpha$ syn caused a decrease in the $\mathrm{PKC} \delta$ promoter activity. For this, a $1.7 \mathrm{~kb}(-1700 /+22$, relative to the transcription start site) region of the rat $\mathrm{PKC} \delta$ promoter was amplified and cloned into the pGL3-Basic reporter vector. The promoter activity was then studied by transfecting $\alpha$ syn-expressing and vector control N27 cells with the reporter construct pGL3-PKC $\delta$ carrying $\mathrm{PKC} \delta$ promoter. As shown in Figure $4 C$, compared with vector control cells, $\alpha$ syn resulted in a significant decrease $(p<0.001)$ in luciferase activity, suggesting that $\alpha$ syn-induced suppression of PKC $\delta$ is most likely mediated at the level of transcription.

positive cells lost their $\mathrm{PKC} \delta$ expression in $\alpha$ syn-transgenic mice (Fig. 3B) compared with control mice. Similar results were obtained by quantifying TH-PKC $\delta$-colocalized dopaminergic neurons in a delineated area (data not shown). Western blot analysis confirmed an approximately sixfold increase in the levels of $\alpha$ syn in the substantia nigra of $\alpha$ syn-transgenic mice (Fig. 3C). Overall, these results establish an in vivo relevance of the relationship between $\alpha$ syn overexpression and PKC $\delta$ expression in dopaminergic neurons.

\section{$\alpha$-Synuclein attenuates $\operatorname{PKC} \delta$ promoter activation and transcription efficiency without affecting $\mathrm{PKC} \delta$ protein turnover or mRNA stability}

We next investigated the molecular mechanism underlying the $\alpha$ syn-induced suppression of PKC $\delta$ expression. First, we examined whether $\alpha$ syn could destabilize PKC $\delta$ protein in N27 cells. To this end, we investigated the PKC $\delta$ turnover rate by performing a pulse-chase experiment on both $\alpha$ syn-expressing and vector control N27 cells labeled with $\left[{ }^{35} \mathrm{~S}\right]$ methionine. $\alpha$ Syn had no effect on PKC $\delta$ protein turnover (Fig. $4 A$ ). The relative half-life of PKC $\delta$ was estimated to be $14.77 \mathrm{~h}$ in vector control and 14.07 $\mathrm{h}$ in $\alpha$ syn-expressing $\mathrm{N} 27$ cells (degradation rate constant $K=$ $0.055 \pm 0.017$ per hour in vector control cells vs $0.051 \pm 0.007$ per hour in $\alpha$ syn-expressing cells), an insignificant difference between the two cells. We also considered the possibility that $\alpha$ syn might directly alter the PKC $\delta$ mRNA instability. To address this possibility, we measured PKC $\delta$ mRNA half-life by treating cells with the transcription inhibitor ActD for 0-12 h, and quan-
Next, we used a nuclear run-on assay to investigate the effects of $\alpha$ syn on PKC $\delta$ transcriptional rate. In this assay, nuclei were isolated from either $\alpha$ syn-expressing or vector control N27 cells and used with the reaction containing biotin-16-UTP. We also prepared nuclei from vector control cells and incubated without biotin-16-UTP as a negative control for the run-on reaction. After the transcriptional reaction, total nuclear RNA was extracted, and then biotinylated RNA was isolated using streptavidin magnetic beads. qRT-PCR analysis was conducted with the biotinylated RNA and total nuclear RNA pools. Figure $4 D$ shows the representative amplification plots for PKC $\delta$ mRNA (left panel) and $\beta$-actin mRNA (right panel). The amount of biotinylated PKC $\delta$ mRNA generated in nuclei from $\alpha$ syn-expressing cells was lower than that obtained from vector control cells, but $\beta$-actin mRNA levels were nearly identical, indicating that $\alpha$ syn specifically inhibits the PKC $\delta$ transcriptional rate. Quantitative analysis showed a significant reduction $(p<0.001)$ in the $\mathrm{PKC} \delta$ transcription efficiency in $\alpha$ syn-expressing cells (Fig. $4 E$ ). Collectively, the results of the run-on experiment, combined with the promoter reporter analysis, strongly suggest the involvement of a transcriptional repression mechanism in the regulation of PKC $\delta$ expression. In addition, we also explored the possibility that epigenetic mechanisms such as DNA methylation (supplemental Fig. 2A, available at www.jneurosci.org as supplemental material) may be responsible for the $\alpha$ syn-induced reduction in PKC $\delta$. Examination of the methylation status of the rat $\mathrm{PKC} \delta$ promoter by MSP analysis (supplemental Fig. $2 B$, available at www. jneurosci.org as supplemental material) revealed an identical 
A
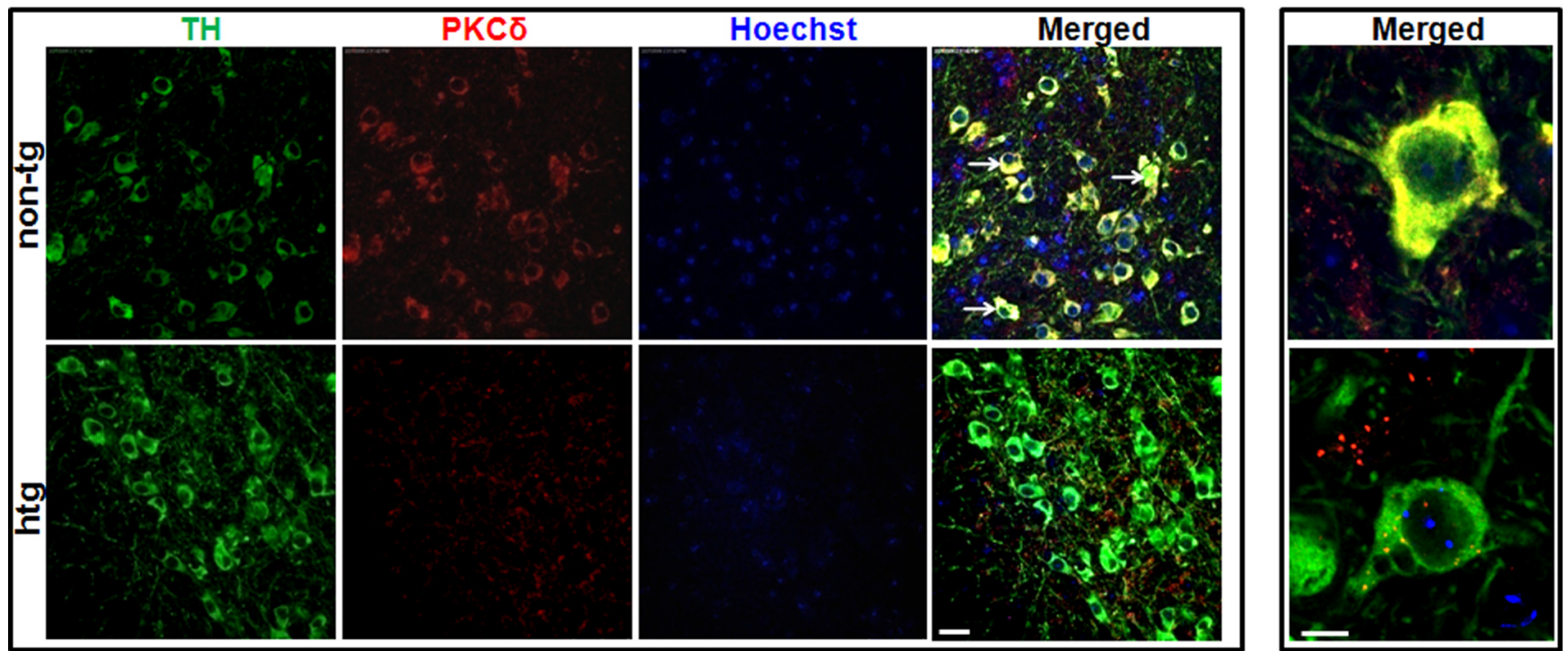

$63 x$

$430 x$
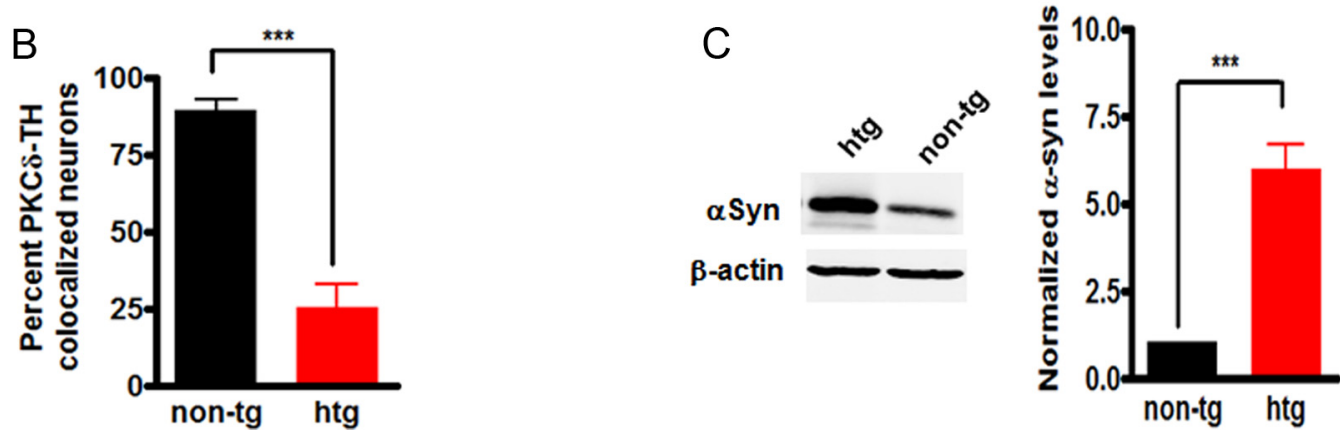

Figure 3. Decreased PKC $\delta$ expression in nigral dopaminergic neurons in $\alpha$-synuclein-overexpressing mice. $A$, Representative images of immunohistochemical analysis of PKC $\delta$ expression within nigral TH-positive neurons. Substantia nigra sections from nontransgenic control (non-tg) mice and $\alpha$ syn-transgenic mice (htg) were stained with PKC $\delta$ polyclonal antibody (1:250 dilution) and TH monoclonal antibody (1:1800 dilution), followed by incubation with Alexa 568-conjugated (red; 1:1000) and Alexa 488-conjuated (green; 1:1000) secondary antibodies. Hoechst 33342 (10 $\mu \mathrm{g} / \mathrm{ml}$ ) was added to stain the nucleus. Confocal images were obtained using a Leica SP 5 X confocal microscope system. Green, TH; red, PKC $\delta$; blue, nucleus. The white arrows point to dopaminergic neurons with significant PKC $\delta$ staining. Scale bars: Left panel, $25 \mu \mathrm{m}$; right panel, $7.5 \mu \mathrm{m}$. Magnifications: Left panel, $63 \times$; right panel, $430 \times$. $B$, Quantification of the number of TH neurons containing colocalized PKC $\delta$ immunoreactivity was determined by blindly counting six fields and averaging. Values expressed as percentage of total TH neurons were mean \pm SEM and representative for results obtained with three pairs of 6- to 8-week-old mice (*** $p<0.001)$. C, To analyze the levels of $\alpha$ syn in substantial nigra homogenates from transgenic mice overexpressing human wild-type $\alpha$ syn and nontransgenic mice, substantial nigra homogenates were prepared from transgenic mice (htg) and nontransgenic mice (non-tg) and subjected to immunoblotting analysis of $\alpha$ syn and $\beta$-actin. Representative immunoblot (left panel) and quantitation (right panel) of $\alpha$ syn expression were shown. Approximately sixfold increase in $\alpha$ syn expression in substantial nigra was found in transgenic mice. Data were shown as mean $\pm \mathrm{SEM} ; n=6\left(^{* * *} p<0.001\right)$.

methylation pattern in $\alpha$ syn-expressing and vector cells, suggesting that the hypermethylation mechanism is less likely to be involved in the repression of PKC $\delta$.

Increased $\alpha$-synuclein expression suppresses PKC $\delta$ in part by blocking NF $\kappa$ B activation

To further explore the mechanism of $\alpha$ syn inhibition of the PKC $\delta$ promoter activity, the rat $\mathrm{PKC} \delta$ proximal promoter $(-178$ to +22 ) was aligned for comparison with the homologous sequences from the murine, human, and bovine genome (supplemental Fig. 3, available at www.jneurosci.org as supplemental material). Murine PKC $\delta$ and human PKC $\delta$ promoters were well conserved from 89 to $71 \%$ compared with rats, although the same region was less conserved in the bovine PKC $\delta$ gene (59\%). Additional analysis revealed six highly conserved transcription factor binding sites (TFBSs) in the proximal promoter (supplemental Fig. 3, available at www.jneurosci.org as supplemental material). Among these conserved TFBSs, the most notable were two potential NF $\kappa \mathrm{B}$ binding sites, located at positions -20 to -8 (designated as $\mathrm{Pkc} \delta \mathrm{NF} \kappa \mathrm{B} 1$ ) and -50 to -38 (designated as $\mathrm{Pkc} \delta \mathrm{NF} \kappa \mathrm{B} 2)$. They are in close proximity, providing an enticing platform for $\mathrm{NF} \kappa \mathrm{B}$ binding and transactivation of the $\mathrm{PKC} \delta$ gene. Additionally, a previous report indicated that $\mathrm{NF} \kappa \mathrm{B}$ may be involved in mouse PKC $\delta$ expression (Suh et al., 2003). Therefore, we performed detailed studies on the role of these two $\kappa \mathrm{B}$ sites in the regulation of basal PKC $\delta$ expression in N27 cells and also elucidated whether $\mathrm{NF} \kappa \mathrm{B}$ plays a role in $\alpha$ syn-mediated downregulation of PKC $\delta$ expression. To determine whether these sites were able to bind NF $\kappa$ B, we performed EMSA using the $\kappa \mathrm{B}$ site sequence of $\mathrm{PKC} \delta$ promoter as a probe and nuclear extracts from vector cells as a source of $\mathrm{NF} \kappa \mathrm{B}$ (oligonucleotides sequences used in EMSA are listed in supplemental Table 2, available at www. jneurosci.org as supplemental material). As shown in Figure 5A, in the absence of nuclear extract, the labeled probe is detected as free probe migrating at the gel front (lane 1). In contrast, in the presence of nuclear extract, an intense shifted band is seen in EMSA using Pkc $\delta \mathrm{NF} \kappa \mathrm{B} 1$ (left panel) or $\mathrm{Pkc} \delta \mathrm{NF} \kappa \mathrm{B} 2$ (right panel) as a probe (Fig. $5 A$, lane 2). Sequence specificity of the DNA- 


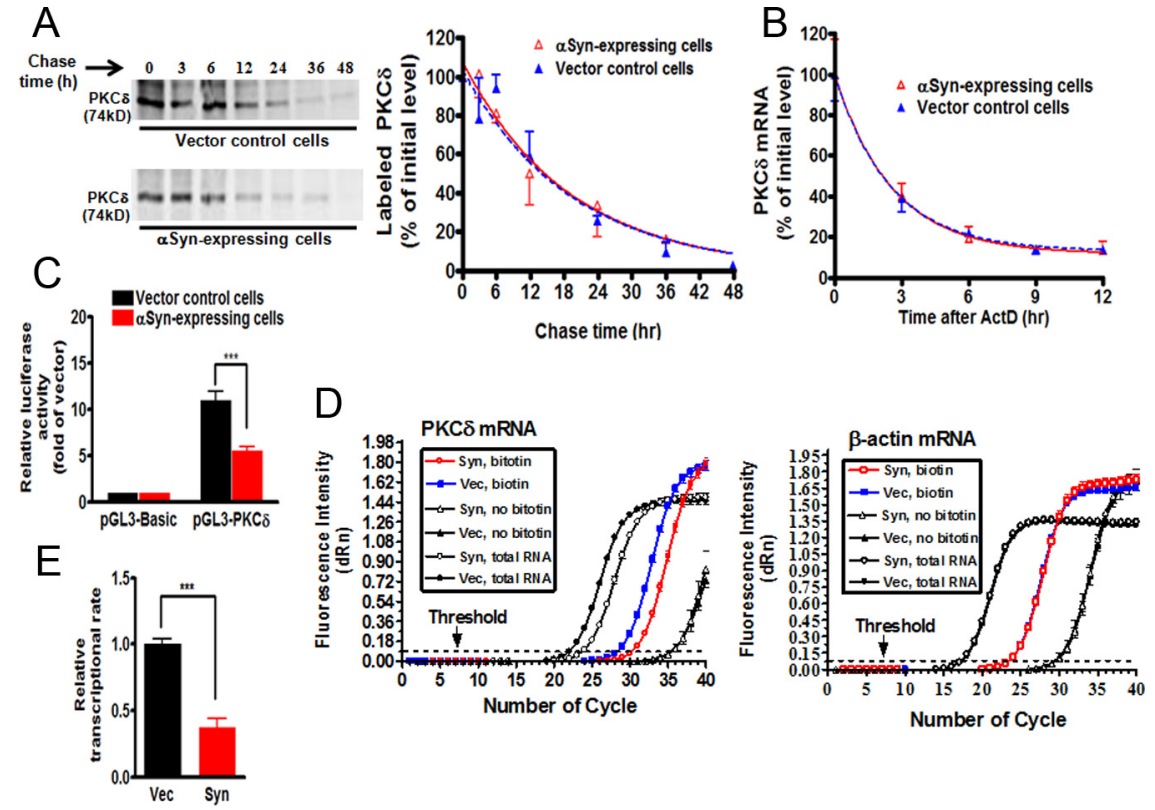

Figure 4. $\alpha$-Synuclein suppresses PKC $\delta$ transcription without affecting PKC $\delta$ protein or mRNA stability in N27 dopaminergic cells. $A$, Left, Pulse-chase analysis of stability of PKC $\delta$ protein. $\alpha$ Syn-expressing and vector control N27 cells were labeled with $\left[{ }^{35}\right.$ S]methionine, and PKC $\delta$ protein was analyzed over $48 \mathrm{~h}$ as described in Materials and Methods. Right, The bands were quantified and expressed as percentage of amount present at time $0 \mathrm{~h}$. The data plotted were fit to a one-phase exponential decay model using the nonlinear regression analysis program of Prism 4.0 software as follows: $Y=$ span $e^{-K t}+$ plateau, where $Y$ starts at span + plateau and decays with a rate constant $K$. The half-life of the protein was determined by $0.693 / K$. The square of the correlation coefficient $\left(R^{2}\right)$ is used as a measure of goodness-of-fit in regression analysis. Values are mean \pm SEM of two independent experiments. $\boldsymbol{B}$, The stability of PKC $\delta$ mRNA was not decreased in $\alpha$ syn-expressing N27 cells. After treatment with ActD, total RNA was extracted for qRT-PCR analysis at selected time intervals. The relative abundance of PKC $\delta$ mRNA was expressed as a percentage of that present at time $0 \mathrm{~h}$, and data plotted were fit to the one-phase exponential decay model. Values are mean \pm SEM of three independent experiments performed in triplicate. $C$, The PKC $\delta$ promoter activation was attenuated in $\alpha$ synexpressing cells in reporter assays. Reporter pGL3-PKC $\delta$ carrying the PKC $\delta$ promoter or pGL3-Basic empty vector was transiently transfected into $\alpha$ syn-expressing and vector control cells. Cells were collected $24 \mathrm{~h}$ after transfection and assayed for luciferase activity and $\beta$-galactosidase activity. Data were normalized and expressed as fold induction over the pGL3-Basic vector. Values are shown as mean \pm SEM of three independent experiments performed in triplicate $\left.{ }^{* * *} p<0.001\right)$. D , The relative transcription efficiency of PKC $\delta$ was examined by quantitative nuclear run-on assay. Representative amplification plots for PKC $\delta$ mRNA (left panel) and $\beta$-actin mRNA (right panel) are shown. The change in fluorescence intensity $(\Delta \mathrm{Rn})$ was plotted on the $y$-axis. The arrow shows the threshold (dashed lines). $\boldsymbol{E}$, Quantitation of transcription efficiency. Data are expressed as fold change in the level of nascent run-on PKC $\delta$ mRNA in vector control cells and are shown as mean \pm SEM of three independent experiments performed in triplicate $(* * * 00.001)$.

protein complex was shown by competition with excess of selected unlabeled oligos. The addition of excess unlabeled selfoligos, or NF $\kappa \mathrm{B}$ consensus oligos, resulted in the ablation of this DNA-protein complex (Fig. 5A, lanes 3 and 5). However, an excess of unlabeled mutant $\mathrm{Pkc} \delta \mathrm{NF} \kappa \mathrm{B}$ oligos, or unrelated AP1 consensus oligos, did not interrupt the binding of nuclear proteins (Fig. 5A, lanes 4 and 6). In addition, parallel EMSA using $\mathrm{NF} \kappa \mathrm{B}$ consensus sequence as probe also confirmed that the PKC $\delta$ promoter-specific $\kappa \mathrm{B}$ sites can compete efficiently against the $\mathrm{NF} \kappa \mathrm{B}$ consensus sequence for binding $\mathrm{NF} \kappa \mathrm{B}$ (data not shown). Thus, these data clearly demonstrate that the $\mathrm{PKC} \delta$ promoter has two functional $\mathrm{NF} \kappa \mathrm{B}$ binding sites.

To further characterize $\mathrm{NF} \kappa \mathrm{B}$ binding to the $\mathrm{PKC} \delta$ promoter, we performed supershift assay using $\mathrm{Pkc} \delta \mathrm{NF} \kappa \mathrm{B} 1$ as a probe and nuclear extracts from vector cells. As shown in Figure $5 B$, in the absence of antibodies, $\mathrm{NF} \kappa \mathrm{B}$ binding to the $\mathrm{Pkc} \delta \mathrm{NF} \kappa \mathrm{B} 1$ probe was again observed (lane 1), and competition with an excess of self oligos was included as an internal control (lane 2). In the presence of anti-p65 antibody, the protein-DNA complex was interrupted, and a specific supershift band was formed (lane 4). This effect was also observed with the complete ablation of pro-
tein-DNA complex and the formation of an intense supershift band when we added anti-p65 and anti-p50 together (lane 5). In the presence of anti-p50 antibody alone, however, no supershift was formed but the protein-DNA complex was significantly reduced (lane 3 ). The lack of a clear supershift with p50 antibody may be attributable to the interruption of the formation of protein-DNA complex by exposure to a specific antibody (Gustin et al., 2004). Normal rabbit IgG antibody displayed no effect on the formation of the protein-DNA complex. Thus, our data demonstrated that $\mathrm{NF} \kappa \mathrm{B}$ is constitutively activated in N27 cells and that the activated $\mathrm{NF} \kappa \mathrm{B}$ bound to the PKC $\delta$ promoter composed of a p50/p65 heterodimer.

If $\alpha$ syn inhibits the PKC $\delta$ promoter activity through the $\mathrm{NF} \kappa \mathrm{B}$ cis-elements at the $\mathrm{PKC} \delta$ promoter, we should see a decrease in the $\mathrm{NF} \kappa \mathrm{B}-\mathrm{DNA}$ complex in $\alpha$ syn-expressing cells. As expected, the nuclear extracts (both 5 and $10 \mu \mathrm{g}$ ) from $\alpha$ syn-expressing cells exhibited reduced DNA binding activity to the $\mathrm{Pkc} \delta \mathrm{NF} \kappa \mathrm{B} 1$ probe compared with vector control cells (Fig. 5C). A similar result was obtained when the labeled $\mathrm{Pkc} \delta \mathrm{NF} \kappa \mathrm{B} 2$ probe was used (data not shown). Based on these findings, we then performed a ChIP assay to analyze the effect of $\alpha$ syn on NF $\kappa \mathrm{B}$ activation in vivo. As shown in Figure $5 D$, $\alpha$ syn expression diminished endogenous binding of both p 65 and p 50 to the PKC $\delta$ promoter. No detectable signal was observed in the absence of antibody in the immunoprecipitation process. To further confirm the inhibitory effect of $\alpha$ syn on $\mathrm{NF} \kappa \mathrm{B}$ transactivation, parallel studies using RNA interference to downregulate $\alpha$ syn were performed. For this study, we transfected siRNA- $\alpha$ syn (si- $\alpha$ syn) into $\alpha$ syn-expressing cells and then examined the $\mathrm{NF} \kappa \mathrm{B}$ binding to the $\kappa \mathrm{B}$ element of the PKC $\delta$ promoter at $72 \mathrm{~h}$ after transfection. EMSA showed that $\mathrm{NF} \kappa \mathrm{B}$ activity was dramatically increased in $\alpha$ syn knockdown samples (Fig. $5 E$ ). The efficacy of $\alpha$ syn-siRNA was evaluated by Western blot, and a 90\% reduction in the $\alpha$ syn level was obtained compared with the negative control siRNA and mock transfected control (data not shown). Finally, we characterized the requirement of $\mathrm{NF} \kappa \mathrm{B}$ for constitutive PKC $\delta$ expression in N27 cells. To this end, we used NF $\kappa \mathrm{B}-\mathrm{p} 65$ siRNA to directly inhibit the p 65 protein. When N27 cells were transfected with siRNA-p65 (si-p65), a $\sim 56 \%$ reduction in the $\mathrm{p} 65$ level was observed, correlating with a concomitant $\sim 35 \%$ decrease in the PKC $\delta$ protein level. However, the negative control siRNA and mock transfection control did not show a significant effect on the levels of p65 or PKC $\delta$ proteins (Fig. $5 F$ ). Collectively, these results indicate that $\mathrm{NF} \kappa \mathrm{B}$ plays an important role in $\mathrm{PKC} \delta$ transactivation in N27 cells and that $\alpha$ syn-induced downregulation of PKC $\delta$ expression was mediated, at least in part, by reducing the $\mathrm{NF} \kappa \mathrm{B}$ binding to $\kappa \mathrm{B}$ enhancer elements at the PKC $\delta$ promoter. 
To further confirm the functional role of $\mathrm{NF} \kappa \mathrm{B}$ in the regulation of PKC $\delta$ gene expression in primary dopaminergic neurons, mouse primary mesencephalic cultures were treated with the $\mathrm{NF} \kappa \mathrm{B}$ inhibitor SN-50, a cell-permeable peptide that blocks $\mathrm{NF} \kappa \mathrm{B}$ nuclear translocation (de Erausquin et al., 2003), and PKC $\delta$ immunoreactivity of TH-positive neurons was analyzed immunocytochemically (Fig. 6). Exposure of primary mesencephalic cultures to SN-50 (100 $\mu \mathrm{g} / \mathrm{ml})$ for $24 \mathrm{~h}$ induced a significant reduction in $\mathrm{PKC} \delta$ immunoreactivity in TH-positive neurons (Fig. 6A). Analysis of fluorescent intensity with MetaMorph Image analysis software revealed a $\sim 70 \%(p<0.01)$ decrease in $\mathrm{PKC} \delta$ immunoreactivity in $\mathrm{SN}$ 50-treated TH-positive neurons (Fig. 6B). Also, the SN-50 (100 $\mu \mathrm{g} / \mathrm{ml})$-treated culture showed reduced p65 level in the nucleus, confirming the inhibitory effect of $\mathrm{SN}-50$ on $\mathrm{NF} \kappa \mathrm{B}$ activation (data not shown). These results confirm that $\mathrm{NF} \kappa \mathrm{B}$ is an important regulator of $\mathrm{PKC} \delta$ expression in cultured substantia nigral neurons, and thus additional analyses were performed to examine the mechanism of action of $\alpha$ syn in inhibiting NF $\kappa$ B activity to downregulate $\mathrm{PKC} \delta$ expression.

$\alpha$-Synuclein-induced blockade of NF $\kappa \mathrm{B}$ activation is associated with decreased acetylation of p65, but does not correlate with alteration of nuclear translocation or protein levels of $\mathrm{NF} \boldsymbol{\kappa} \mathrm{B} / \mathrm{I} \boldsymbol{\kappa} \mathrm{B} \boldsymbol{\alpha}$

Our next objective was to explore the molecular basis of inhibition of $\mathrm{NF} \kappa \mathrm{B}$ activity by $\alpha$ syn. Since $\alpha$ syn is predominantly located in the cytoplasm (supplemental Fig. 1, available at www.jneurosci.org as supplemental material), the inhibitory effect of $\alpha$ syn on $\mathrm{NF} \kappa \mathrm{B}$ activity may be attributable to its interaction with $\mathrm{NF} \kappa \mathrm{B}$ in the cytoplasm, preventing $\mathrm{NF} \kappa \mathrm{B}$ localization to the nucleus. However, in our experimental conditions, we were unable to detect physical interactions between $\alpha$ syn and $\mathrm{NF} \kappa \mathrm{B}$ subunits or $\mathrm{I} \kappa \mathrm{B} \alpha$ by coimmunoprecipitation analysis (data not shown). It may also be possible for $\alpha$ syn to indirectly modulate NF $\kappa \mathrm{B}$ activity by enhancing the cytoplasmic retention of $\mathrm{p} 50 / \mathrm{p} 65$ or altering cellular pools of $\mathrm{I} \kappa \mathrm{B} \alpha$. To test this possibility, the subcellular distribution of $\mathrm{NF} \kappa \mathrm{B}$ p50/p65 and $\mathrm{I} \kappa \mathrm{B} \alpha$ was compared between $\alpha$ syn-expressing cells and vector control N27 cells. Surprisingly, $\alpha$ syn did not have any effect on $\mathrm{p} 50 / \mathrm{p} 65 \mathrm{NF} \kappa \mathrm{B}$ subunits or $\mathrm{I} \kappa \mathrm{B} \alpha$ in both cytoplasmic and nuclear fractions (Fig. 7A). To further determine whether reduced $\mathrm{NF} \kappa \mathrm{B} / \mathrm{DNA}$ binding ac-

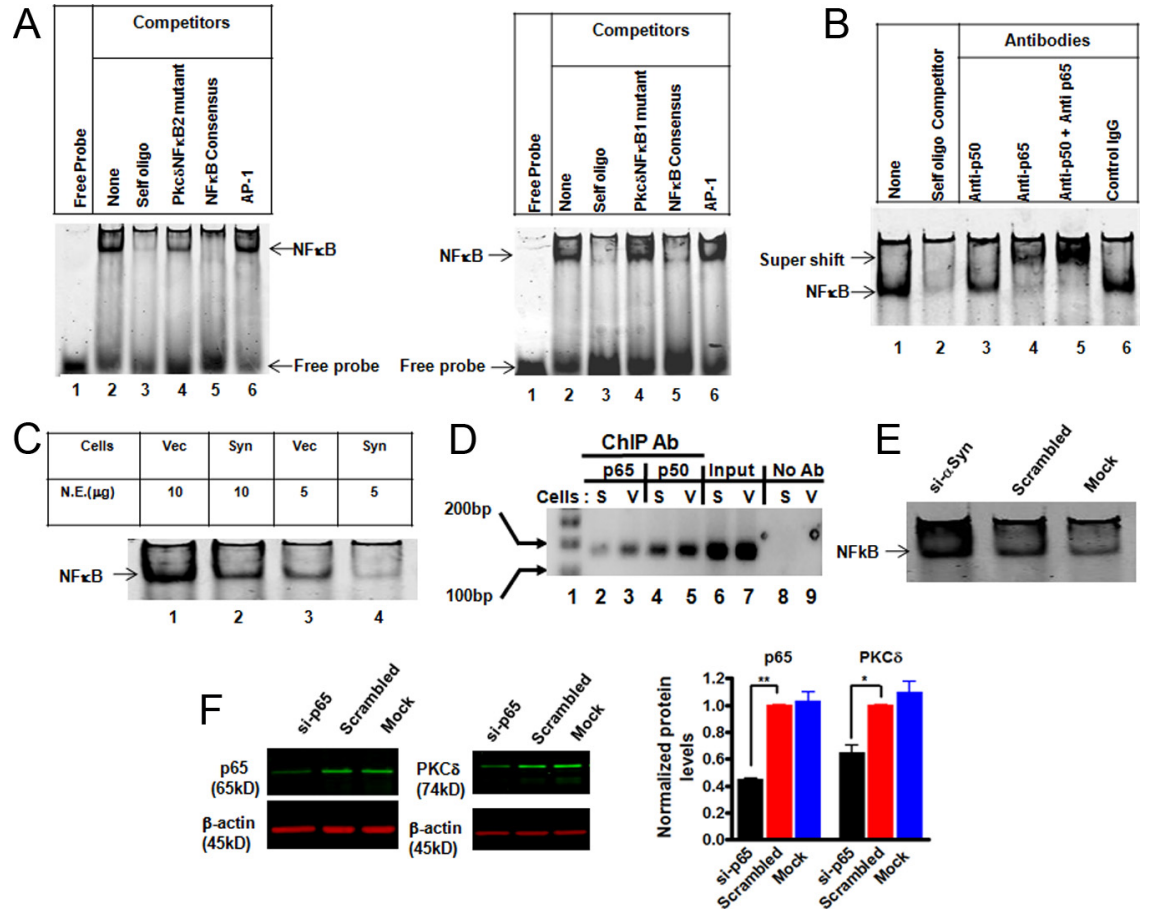

Figure 5. Increased $\alpha$-Synuclein expression suppresses PKC $\delta$ in part by blocking NF $\kappa$ B activation. $\boldsymbol{A}$, Representative EMSA gel images show the direct binding of NF $\kappa$ B to the putative PKC $\delta$ NF $\kappa$ B sites. Competitive EMSA was conducted using labeled probe corresponding to the PKC $\delta$ NF $\kappa$ B site 1 (left panel) or the PKC $\delta$ NF $\kappa$ B site 2 (right panel) and indicated unlabeled oligos. $\boldsymbol{B}$, Binding $\mathrm{p} 50$ and $\mathrm{p} 65$ to the $\mathrm{NF} \kappa \mathrm{B}$ sites on the PKC $\delta$ promoter. The nuclear extracts from vector control cells were incubated with excess of unlabeled self-oligos or indicated antibodies before adding the labeled probe (PKC $\delta$ NF $\kappa B$ site 1). A representative EMSA supershift gel from three independent experiments is shown. $C$, A representative EMSA gel image indicates the reduced binding of NF $\kappa B$ in vitro to the PKC $\delta$ NF $\kappa$ B site 1 in $\alpha$ syn-expressing N27 cells. D, ChIP analysis of the in vivo binding of NF $\kappa$ B-p65 and p50 on the PKC $\delta$ promoter. After reversal of cross-linking, immunoprecipitated genomic DNA fragments were analyzed by PCR using primers designed to amplify the -103 to +60 region of PKC $\delta$ promoter. $E$, Knockdown of $\alpha$ syn protein increased NF $\kappa$ B activity. $\alpha$ Synexpressing cells were transient transfected with siRNA- $\alpha$ syn and scrambled siRNA. Seventy-two hours after transfection, the cells were collected and subjected to EMSA analysis using the labeled probe corresponding to the PKC $\delta$ NF $\kappa$ B site 1. Mock transfection was also included as a negative control. $\boldsymbol{F}$, Transfection of NF $\kappa$ B-p 65 siRNA downregulated PKC $\delta$ expression in N27 cells. N27 cells were transfected with p65-siRNA and scrambled siRNA for $96 \mathrm{~h}$, and cells were collected for Western blot analysis. Representative immunoblot (left panel) and quantitation (right panel) of p 65 and PKC $\delta$ on whole-cell lysates in transfected cells. Data are shown as mean \pm SEM of two independent experiments $\left({ }^{*} p<0.05 ;{ }^{* *} p<0.01\right)$.
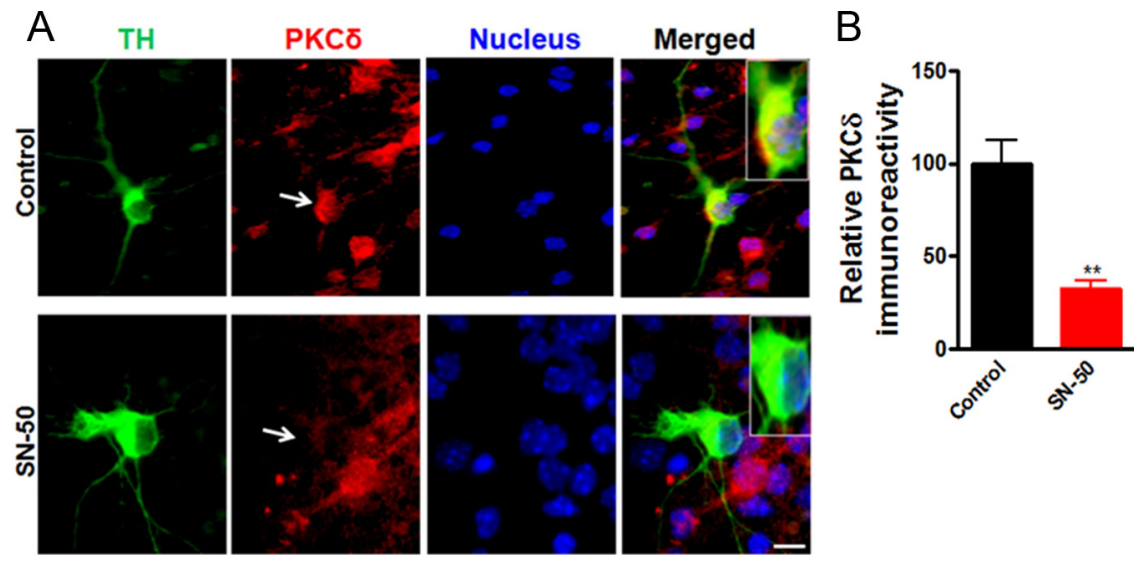

Figure 6. Effect of $\mathrm{NF} \kappa \mathrm{B}$ inhibition on the $\mathrm{PKC} \delta$ immunoreactivity in the primary dopaminergic neurons. $A$, Primary midbrain cultures were treated with or without $100 \mu \mathrm{g} / \mathrm{mI} \mathrm{SN}-50$ for $24 \mathrm{~h}$. Cultures were immunostained for TH (green) and PKC $\delta$ (red). The nuclei were counterstained by Hoechst 33342 (blue). Images were obtained using a Nikon TE2000 fluorescence microscope. Magnification, $60 \times$. Scale bar, $10 \mu \mathrm{m}$. Representative immunofluorescence images are shown. The inset shows a higher magnification of the cell body area. $\boldsymbol{B}$, Immunofluorescence quantification of PKC $\delta$ in TH-positive neurons. Fluorescence immunoreactivity of PKC $\delta$ was measured from TH-neurons in each group using MetaMorph software. Values expressed as percentage of control group are mean \pm SEM and representative for results obtained from three separate experiments in triplicate $\left({ }^{* *} p<0.01\right)$. 

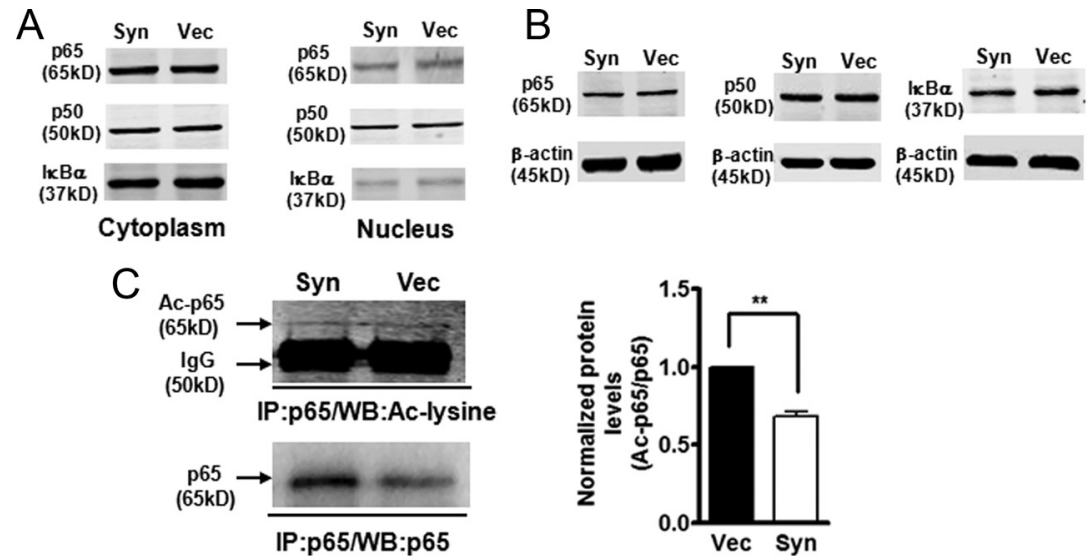

\section{$\mathrm{D}$}

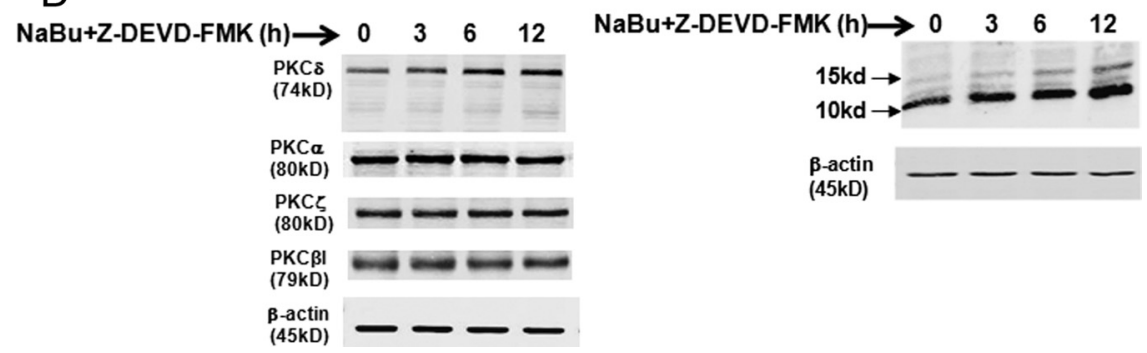

Figure 7. $\alpha$-Synuclein-induced blockade of NF $\kappa$ B activation is associated with decreased acetylation of $p 65$ but does not correlate with nuclear translocation or protein levels of $\mathrm{NF} \kappa \mathrm{B} / \mathrm{I} \kappa \mathrm{B} \alpha . A, B$, Nuclear translocation and abundance of $\mathrm{NF} \kappa \mathrm{B} / \mathrm{I} \kappa \mathrm{B} \alpha$ were not altered by overexpression of $\alpha$ syn. Representative immunoblot of $p 65, p 50$, and $\mid \kappa B \alpha$ levels on cytoplasmic and nuclear extracts $(\boldsymbol{A})$ or whole-cell lysates $(\boldsymbol{B})$ from $\alpha$ syn (Syn) and vector control (Vec) cells. $\boldsymbol{C}$, The p65 acetylation levels were reduced in $\alpha$ syn cells. Whole-cell lysates was immunoprecipitated (IP) with p65 antibody. The resulting immunoprecipitates were blotted with anti-acetyl-lysine and anti-p65 antibodies. Densitometric quantitation of the ratio of band intensity of acetylated $p 65$ and total p65 from two independent experiments (means \pm SEM; $\left.{ }^{* *} p<0.01\right)$ is shown on the right. $\boldsymbol{D}$, Sodium butyrate $(\mathrm{NaBu})$ specifically enhanced PKC $\delta$ isoform expression in $\alpha$ syn-expressing N27 cells. $\alpha$ Syn-expressing cells were treated with $1 \mathrm{~mm} N \mathrm{NaBu}$ and $50 \mu \mathrm{m}$ caspase-3 inhibitor Z-DEVD-FMK, and cell lysates were prepared for blotting with specific anti-PKC isoforms (left panel) and anti-acetyl-lysine (right panel) antibodies.

tivity by $\alpha$ syn resulted from alteration of protein levels of $\mathrm{NF} \kappa \mathrm{B}$ subunits and $\mathrm{I} \kappa \mathrm{B} \alpha$, we analyzed $\mathrm{p} 65, \mathrm{p} 50$, and $\mathrm{I} \kappa \mathrm{B} \alpha$ by Western blot. As shown in Figure $7 B$, the total protein levels of $\mathrm{p} 65$, p50, and $\mathrm{I} \kappa \mathrm{B} \alpha$ were not affected by $\alpha$ syn either.

Studies were then undertaken to determine whether $\alpha$ synmediated downregulation of $\mathrm{NF} \kappa \mathrm{B}$ activity might be related to $\mathrm{NF} \kappa \mathrm{B} / \mathrm{p} 65$ acetylation, a nuclear event associated with increased transactivation potential of $\mathrm{NF} \kappa \mathrm{B}$ and regulated by both $\mathrm{p} 300 /$ CBP HAT and histone deacetylase 3 (HDAC3) (Chen et al., 2001, 2002). In this experiment, whole-cell extracts were immunoprecipitated with a p65 antibody, and acetylated p65 (Ac-p65) was detected by Western blot using an antibody specific for acetylated lysine. Total p 65 proteins from immunoprecipitates were then reprobed with the p65 antibody. As shown in Figure 7C, a $\sim 65$ $\mathrm{kDa}$ acetylated p65 showed no overt differences in acetylated p65, but the total p65 levels immunoprecipitated from $\alpha$ synexpressing cells were significantly higher than that from vector control cells, which might be attributable to the different efficiencies achieved during immunoprecipitation steps. Quantification of normalized data (Ac-p65 over total p65) revealed a significant $(p<0.01)$ reduction in Ac-p65 in $\alpha$ syn-expressing cells compared with vector control cells (Fig. $7 C$, right panel). To further confirm the role of $\mathrm{p} 65$ acetylation in the modulation of PKC $\delta$ expression, we used the HDAC inhibitor sodium butyrate, which increased the acetylation of p65 (Duan et al., 2007), possibly by inhibiting HDAC3. We previously reported that certain neurotoxic insults induce $\mathrm{PKC} \delta$ cleavage via a caspase-3-dependent manner (Kaul et al., 2003, 2005a). Since we have found that sodium butyrate markedly induced caspase-3-dependent cleavage of PKC $\delta$ in N27 cells (data not shown), a caspase-3-specific inhibitor Z-DEVD-FMK was applied to prevent the sodium butyrate-induced $\mathrm{PKC} \delta$ cleavage. After cotreatment with sodium butyrate $(1 \mathrm{mM})$ and Z-DEVD-FMK $(50 \mu \mathrm{M})$ in $\alpha$ syn-expressing cells, as expected, total cellular acetylation was significantly enhanced. In particular, two most prominent bands were observed at 15 and $10 \mathrm{kDa}$, respectively (Fig. 7D, right panel). In correlation with this finding, sodium butyrate treatment resulted in a time-dependent increase in PKC $\delta$ protein levels, whereas it had no such effect on the levels of other PKC isoforms $(\alpha, \beta \mathrm{I}, \zeta)$, suggesting that increased cellular acetylation can isoform-specifically upregulate $\mathrm{PKC} \delta$ (Fig. 7D, left panel). Together, these results suggest that $\alpha$ syn inhibition of $\mathrm{NF} \kappa \mathrm{B}$ binding to the $\mathrm{PKC} \delta$ promoter is associated with decreased acetylation of $\mathrm{p} 65$, without alteration of $\mathrm{NF} \kappa \mathrm{B}$ nuclear translocation, $\mathrm{I} \kappa \mathrm{B} \alpha$ degradation, or $\mathrm{NF} \kappa \mathrm{B} / \mathrm{I} \kappa \mathrm{B} \alpha$ protein levels.

\section{$\alpha$-Synuclein downregulates p300 proteins, resulting in decreased p300 HAT activity and inhibition of p300-dependent transactivation of PKC $\delta$ expression}

Because the acetylation of p65 by HATs p300/CBP plays a crucial role in $\mathrm{NF} \kappa \mathrm{B}$ activation, we hypothesized that $\mathrm{p} 300 / \mathrm{CBP}$ may be a target for $\alpha$ syn to inhibit p65 acetylation. First, to determine what effect, if any, $\alpha$ syn would exert on these proteins, we measured levels of p300 and CBP by Western blot. As illustrated in Figure $8 \mathrm{~A}$, the amount of nuclear p300 was strikingly reduced (60\%) in $\alpha$ syn-expressing cells, whereas CBP was unaltered, suggesting a selective decrease in $\mathrm{p} 300$ proteins by $\alpha$ syn. Neither p300 nor CBP can be detected in cytoplasmic fractions as they are predominantly nuclear proteins. To further examine whether the decrease in $\mathrm{p} 300$ proteins was at the mRNA level, the p300 mRNA was measured by qRT-PCR analysis. However, p300 transcript levels were unaffected by $\alpha$ syn (data not shown), suggesting that other mechanisms, such as protein degradation, may be required for the decrease in 3300 proteins. Next, we assessed the effect of reduced p300 on its HAT activity. In this experiment, p300 HAT activity was determined using an in vitro acetylation of the core histone with endogenous $\mathrm{p} 300$ proteins immunoprecipitated from $\alpha$ syn-expressing and vector control cells. As shown in Figure $8 B$, p300 HAT activity decreased by $\sim 70 \%$ in $\alpha$ synexpressing cells compared with vector cells, suggesting that the balance between HAT and HDAC activities in $\alpha$ syn-expressing $\mathrm{N} 27$ cells was altered by $\alpha$ syn. The reduction in p300 HAT activity by $\alpha$ syn therefore appears to be at least in part a consequence of the depletion of p300 protein in $\alpha$ syn-expressing cells. In addition to their intrinsic acetyltransferase activity, p300 and CBP are well known for their roles in bridging multiple sequencespecific transcription factors to general transcriptional machinery to initiate transcription (Chan and La Thangue, 2001). Based 


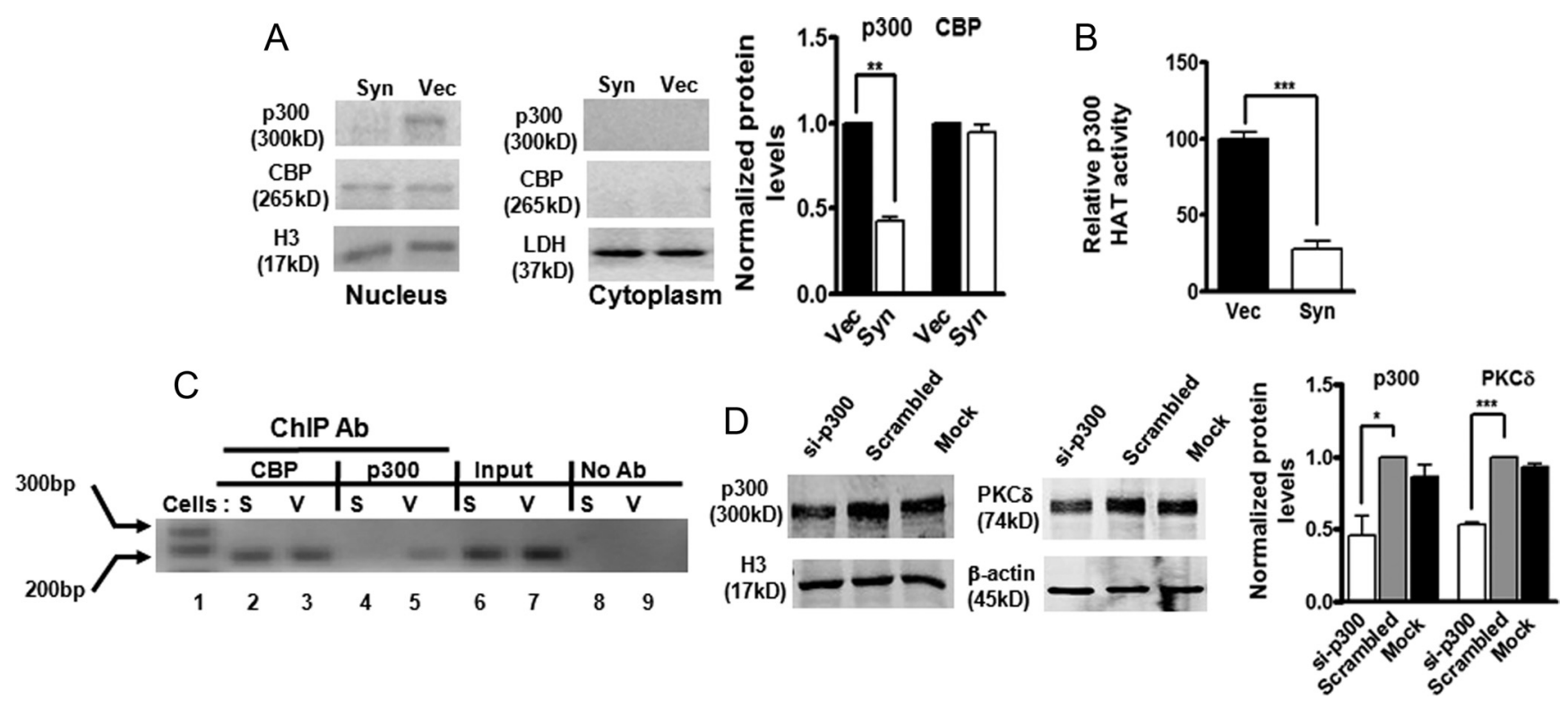

Figure 8. $\alpha$-Synuclein downregulates p300 proteins, resulting in decreased p300 HAT activity and inhibition of p300-dependent transactivation of PKC $\delta$ gene expression. $A$, Decreased p300 protein levels in $\alpha$ syn-expressing cells. Representative immunoblot (left panel) and quantitation (right panel) of p300 and (BP on cytoplasmic and nuclear extracts from $\alpha$ syn-expressing (Syn) and vector control (Vec) cells. Data are shown as mean \pm SEM of two independent experiments ${ }^{* *} p<0.01$ ). LDH (cytoplasmic fraction) or histone H3 (nuclear fraction) was used as loading control. $B$, Decreased p300 HAT activity in $\alpha$ syn-expressing cells. Data were subtracted from background values that were measured in samples containing normal lgG, and then expressed as the percentage of HAT activity present in vector control cells. Values are shown as mean \pm SEM of three independent experiments performed in triplicate $\left.{ }^{* * *} p<0.001\right)$. C, The in vivo binding of $p 300$ on the PKC $\delta$ promoter was interrupted by overexpression of $\alpha$ syn. After reversal of cross-linking, p300-immunoprecipitated genomic DNA fragments were analyzed by PCR using primers designed to amplify the -103 to +60 region of PKC $\delta$ promoter. D, Knockdown of p300 by siRNA-p300 decreased PKC $\delta$ levels in N27 cells. N27 cells were transfected with p300-siRNA and scrambled siRNA for 96 h, and cells were collected for Western blot analysis. Representative immunoblot (left panel) and quantitation (right panel) of p300 and PKC $\delta$ on nuclear extracts or whole-cell lysates in transfected cells. Data are shown as mean \pm SEM of two independent experiments $\left({ }^{*} p<0.05 ;{ }^{* * *} p<0.001\right)$.

on this understanding and our observation of decreased levels of p300 induced by $\alpha$ syn, we were interested in determining whether $\alpha$ syn could modulate p300 transactivation potential by disrupting $\mathrm{p} 300$ recruitment to the $\mathrm{PKC} \delta$ promoter. To address this issue, we evaluated $\mathrm{p} 300$ binding to the $\mathrm{PKC} \delta$ promoter by ChIP assay. Chromatin was immunoprecipitated with a p300 antibody and analyzed by PCR amplification of the PKC $\delta$ promoter region encompassing the $\kappa \mathrm{B}$ binding sites. As shown in Figure $8 C$, a small amount of $\mathrm{p} 300$ binding onto the $\mathrm{PKC} \delta$ promoter was detected in vector control cells, whereas in $\alpha$ synexpressing cells, it was completely abolished (lane 4 vs 5 ). This effect was specific to $\mathrm{p} 300$, as binding and recruitment of CBP to the PKC $\delta$ promoter was not affected by $\alpha$ syn (Fig. $8 C$, lane 2 vs 3 ). Although these experiments demonstrated that $\alpha$ syn blocked p300 association to the PKC $\delta$ promoter, they do not clarify a functional link between loss of p300 and $\alpha$ syn repression of $\mathrm{PKC} \delta$. Therefore, we decided to use siRNA-p300 to directly inhibit endogenous p300 function. As shown in Figure 8D, the transfection of siRNA-p300 (si-p300) into N27 cells resulted in a $\sim 50 \%$ reduction in $\mathrm{p} 300$ protein, which was correlated with a concomitant $\sim 50 \%$ decrease in the PKC $\delta$ protein level. Collectively, these results provide direct evidence for a specific loss of p300 protein and a subsequent decrease in HAT activity attributable to stable expression of $\alpha$ syn, which could account for decreased p65 acetylation and binding activity, as well as downregulation of recruitment and binding of $\mathrm{p} 300$ to the $\mathrm{PKC} \delta$ promoter, which is at least partly responsible for the reduction in PKC $\delta$ expression.

We further examined the role of p300 HAT in controlling PKC $\delta$ expression in primary dopaminergic neurons using the pharmacological modulators of p300. Garcinol, a polyisoprenylated benzophenone derivative isolated from Garcinia indica, has been shown to potently inhibit the activity of p300 and p300/ CBP-associated factor (PCAF) (Balasubramanyam et al., 2004; Arif et al., 2009). In contrast, CTPB, an anacardic acid-inspired benzamide, has been reported to function as an activator of $\mathrm{p} 300$, but not of PCAF (Balasubramanyam et al., 2003; Mantelingu et al., 2007; Souto et al., 2010). We treated mouse primary mesencephalic cultures with either garcinol $(5 \mu \mathrm{M})$ or CTPB $(10 \mu \mathrm{M})$, and then PKC $\delta$ immunoreactivity of TH-positive neurons was determined. As shown in Figure 9A, immunocytochemical staining revealed that the level of PKC $\delta$ immunoreactivity in TH neurons was dramatically reduced by garcinol exposure, and in contrast, CTPB treatment significantly enhanced PKC $\delta$ immunofluorescence. Fluorescent intensity analysis revealed a $\sim 60 \%$ $(p<0.01)$ decrease and $\sim 170 \%(p<0.05)$ increase in PKC $\delta$ immunoreactivity in garcinol-treated and CTPB-treated TH neurons, respectively (Fig. 9B). These results further demonstrated that $\mathrm{p} 300$ can regulate the $\mathrm{PKC} \delta$ expression in primary dopamine neurons. Together with the reduced p300 levels induced by $\alpha$ syn (Fig. 8), these results suggest that inhibition of p300-mediated transcriptional events by $\alpha$ syn could contribute to the downregulation of PKC $\delta$.

\section{Downregulation of p300 in $\alpha$-synuclein-transgenic mice}

Thus far, the in vitro experiments indicated that p300 is likely to be the major target molecule of $\alpha$ syn responsible for the ultimate impingement on the PKC $\delta$ transcription. The final step in our study was to verify whether $\alpha$ syn overexpression downregulates p300 in vivo. To accomplish this, we compared double immunohistochemical labeling of $\mathrm{p} 300$ levels within TH-positive neurons in the substantia nigra of $\alpha$ syn-transgenic (htg) mice versus control (non-tg) animals. As shown in Figure 10, p300 (stained in red) is predominantly distributed in the nucleus in TH-positive 
A
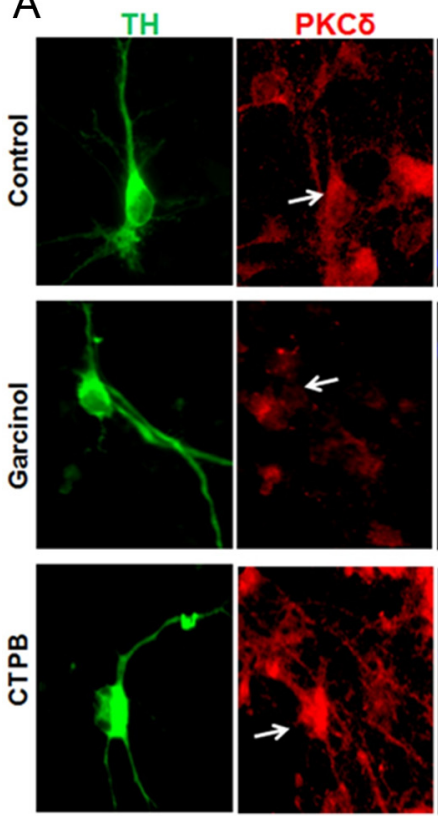
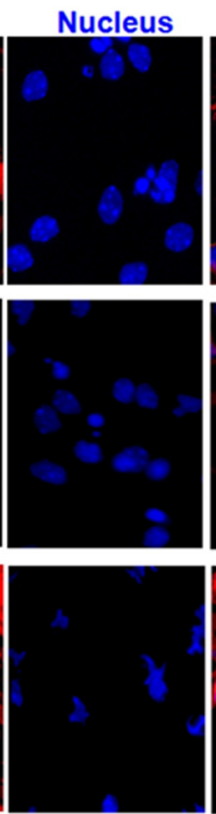
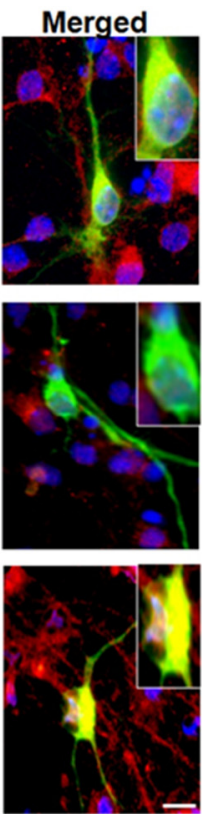

Figure 9. Effect of 300 inhibition or activation on the PKC $\delta$ immunoreactivity in the primary dopaminergic neurons. $A$, Primary midbrain cultures at $7 \mathrm{~d}$ in vitro were treated with or without either $5 \mu \mathrm{m}$ garcinol or $10 \mu \mathrm{M}$ CTPB for $24 \mathrm{~h}$. Cultures were immunostained for TH (green) and PKC $\delta$ (red). The nuclei were counterstained by Hoechst 33342 (blue). Images were obtained using a Nikon TE2000 fluorescence microscope. Magnification, $60 \times$. Scale bar, $10 \mu \mathrm{m}$. Representative immunofluorescence images are shown. The inset shows a higher magnification of the cell body area. $\boldsymbol{B}$, Immunofluorescence quantification of PKC $\delta$ in TH-positive neurons. Fluorescence immunoreactivity of PKC $\delta$ was measured from TH-neurons in each group using MetaMorph software. Values expressed as percentage of control group are mean \pm SEM and representative for results obtained from three separate experiments in triplicate $\left({ }^{*} p<0.05 ;{ }^{* *} p<0.01\right)$.

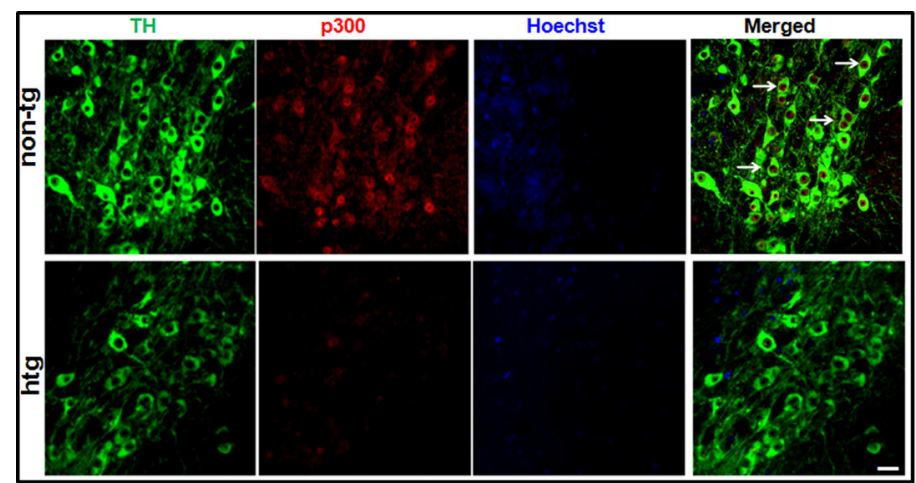

$63 x$

Figure 10. Decreased p300 level within neurons of the substantia nigra in $\alpha$ syn-overexpressing mice. Representative images of immunohistochemical analysis of p300 expression within nigral TH-positive neurons. Substantia nigra sections from nontransgenic control (non-tg) mice and $\alpha$ syn-transgenic mice (htg) were stained with p300 polyclonal antibody (1:350 dilution) and TH monoclonal antibody (1:1800 dilution), followed by incubation with Alexa 568-conjugated (red; 1:1000) and Alexa 488conjugated (green; 1:1000) secondary antibodies. Hoechst $33342(10 \mu \mathrm{g} / \mathrm{ml})$ was added to stain the nucleus. Confocal images were obtained using a Leica SP5 X confocal microscope system. The white arrows point to dopaminergic neurons with significant nuclear p300 staining. Green, TH; red, p300; blue, nucleus. Scale bars: Left panel, $25 \mu \mathrm{m}$; right panel, $7.5 \mu \mathrm{m}$. Magnifications: Left panel, $63 \times$; right panel, $250 \times$.

neurons (stained in green). The majority of TH-positive neurons in control mice exhibited significant p300 expression as shown by the intensive p300 immunoreactivity. In contrast, TH-immunoreactive neurons in $\alpha$ syn-transgenic mice showed weak or no immunoreactivity for $\mathrm{p} 300$. Together with in vitro results, these findings in an animal model clearly demonstrate that the suppression of p300 by $\alpha$ syn contributes to the downregulation of $\mathrm{PKC} \delta$.
B

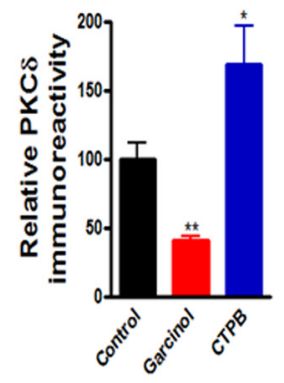

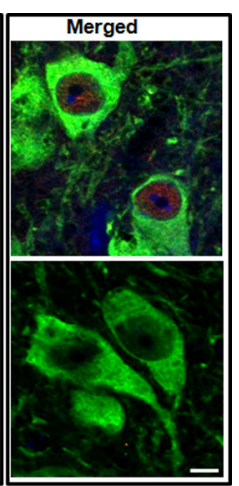

$250 x$

\section{Discussion}

In the present study, we provide evidence that the normal level of human wild-type $\alpha$ syn is able to attenuate the $\mathrm{MPP}^{+}$. induced dopaminergic degeneration by inhibiting the proapoptotic $\mathrm{PKC} \delta$ gene expression. To our knowledge, this is the first evidence that $\alpha$ syn is implicated in modulation of $\mathrm{PKC} \delta$ expression via $\mathrm{p} 300$. Stable expression of human wild-type $\alpha$ syn in N27 dopaminergic cells greatly attenuates the $\mathrm{MPP}^{+}$-induced proteolytic cleavage and nuclear translocation of the PKC $\delta$ catalytic fragment, leading to a neuroprotective effect. Conversely, restoring PKC $\delta$ expression significantly ablates such neuroprotective function. Additionally, we observed that $\mathrm{NF} \kappa \mathrm{B}$ and $\mathrm{p} 300$ are actively involved in the modulation of $\mathrm{PKC} \delta$ gene expression in primary dopaminergic neurons. $\mathrm{NF} \kappa \mathrm{B} / \mathrm{p} 300$ inhibition remarkably reduces the extent of PKC $\delta$ expression in primary dopaminergic neurons, whereas activation of $\mathrm{p} 300$ induces a significantly increased level of PKC $\delta$. Furthermore, we show a dramatically decreased expression of both PKC $\delta$ and p300 proteins in dopaminergic neurons in $\alpha$ syn-transgenic mice. In addition, we systematically characterized the mechanism by which $\alpha$ syn represses PKC $\delta$ gene expression. We demonstrated that $\alpha$ syn does not interfere with $\mathrm{PKC} \delta$ protein and mRNA turnover but acts via direct transcriptional repression. Moreover, we provide evidence linking acetylation events to PKC $\delta$ repression mediated by $\alpha$ syn. First, $\alpha$ syn inhibits $\mathrm{NF} \kappa \mathrm{B}$ acetylation, leading to a reduced $\mathrm{NF} \kappa \mathrm{B}$ transcriptional activity. Second, $\alpha$ syn disrupts p300 HAT activity. Finally, we show that increasing the cellular acetylation by HDAC inhibitor treatment increases PKC $\delta$ expression in an isoform-dependent manner. Collectively, our results support a working model in which $\alpha$ syn acts to inhibit p300 levels and its HAT activity to repress PKC $\delta$ expression and thereby protect against neurotoxicity. These findings might provide mechanistic insights into the physiological role of $\alpha$ syn in regulating neuronal cell death by suppressing the proapoptotic kinase $\mathrm{PKC} \delta$ expression. Our proposed model based on the experimental results is illustrated in Figure 11, in which the inhibition of PKC $\delta$ transcription by cytoplasmic $\alpha$ syn to prevent cell death occurs by disrupting both NF $\kappa \mathrm{B}$ and p300 activation, at least as a consequence of the reduced p300 proteins and subsequent decrease in HAT activity.

$\alpha$ Syn is highly abundant in presynaptic terminals of mammalian brain, making up to $0.1 \%$ of total brain proteins (Iwai et al., 1995 ; Sidhu et al., 2004). Although $\alpha$ syn may have various roles in 


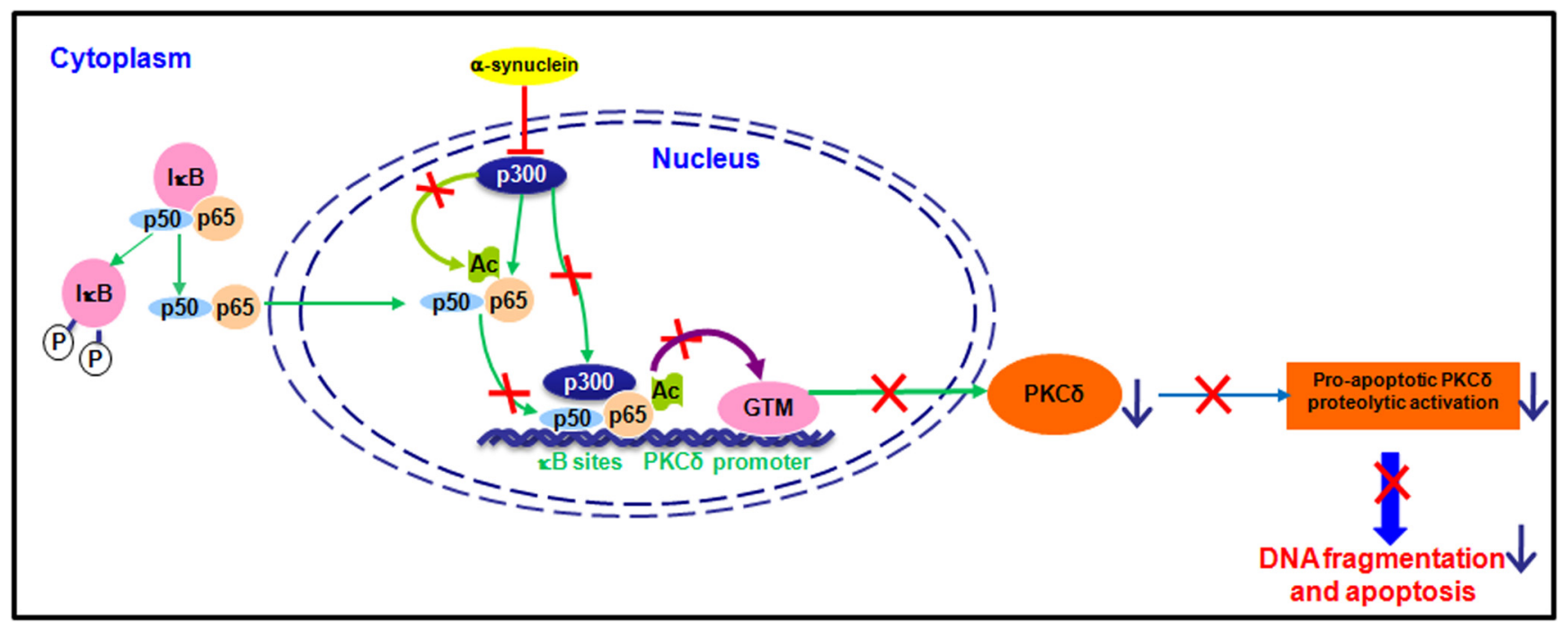

Figure 11. A proposed model for $\alpha$-synuclein acting in the cytoplasm to repress PKC $\delta$ expression and attenuate dopaminergic neurotoxicity. Constitutively activated NF $\kappa$ B p50/p65 heterodimers and p300/CBP bind to the two proximal promoter $\kappa$ B sites and modulate PKC $\delta$ transcription. Expression of $\alpha$ syn, a cytoplasmic protein, inhibits p300-mediated acetylation of p65, thereby blocking the NF $\kappa$ B biding to PKC $\delta$ promoter. In addition, $\alpha$ syn reduces $\mathrm{p} 300$ protein and its HAT activity, resulting in interruption of binding of $\mathrm{p} 300$ to the PKC $\delta$ promoter and its interaction with general transcription machinery (GTM), causing inhibition of PKC $\delta$ transcription. The resulting loss of PKC $\delta$ expression confers protection because of reduced proteolytic activation of PKC $\delta$, which is a key proapoptotic function of the kinase during neurotoxic insults.

dopamine synthesis and homeostasis (Perez et al., 2002; X. Peng et al., 2005), membrane trafficking (Outeiro and Lindquist, 2003; Cooper et al., 2006), synaptic plasticity (Clayton and George, 1998; Stéphan et al., 2002), and as antioxidant or molecular chaperone (Ostrerova et al., 1999; Zhu et al., 2006), its physiological role is still unclear. Mutations in $\alpha$ syn gene promote aggregation of $\alpha$ syn proteins and are linked to PD (Norris et al., 2004). Furthermore, transgenic overexpression of mutant $\alpha$ syn (A53T) in mice produces neurodegeneration (Giasson et al., 2002; Lee et al., 2002). However, controversy remains about the toxicological properties of wild-type $\alpha$ syn. Several lines of wild-type $\alpha$ syntransgenic mice fail to show pathological phenotype (Matsuoka et al., 2001; Rathke-Hartlieb et al., 2001). Furthermore, growing evidence suggests a neuroprotective role for wild-type $\alpha$ syn. For example, wild-type $\alpha$ syn, but not its mutant proteins, protects dopaminergic neurons against $\mathrm{MPP}^{+}$or rotenone toxicity (Jensen et al., 2003). Transgenic mice overexpressing either the wild-type or the A53T mutant $\alpha$ syn are resistant to paraquatinduced dopaminergic cell death (Manning-Bog et al., 2003). The transgenic model used in the current study that overexpresses wild-type human $\alpha$ syn exerts neuroprotection against $\operatorname{CSP} \alpha$ induced neurodegeneration (Chandra et al., 2005). Several hypotheses may explain $\alpha$ syn-mediated neuroprotection. It is conceivable that $\alpha$ syn plays a dual role in the nervous system. When expressed at physiological levels, it may function as a normal protein that contributes to cell survival. In contrast, $\alpha$ syn overexpressed beyond a certain threshold might induce cytotoxicity. A previous study showed that at nanomolar concentrations, $\alpha$ syn prevented cell death, whereas at both low micromolar and overexpressed levels, $\alpha$ syn became neurotoxic (Seo et al., 2002). Since the levels of $\alpha$ syn achieved in our stable N27 cells are within physiological range (Fig. 1A), our results support protective functions of this protein. In addition to the extent of $\alpha$ syn expression, an alternative possibility is that dysregulation of subcellular $\alpha$ syn may contribute to PD. $\alpha$ Syn exists either in a membranebound state that peripherally attaches to vesicles, or in a soluble form that is freely diffusible in the cytoplasm. The translocation between these two subcellular compartments is crucial for the normal function of $\alpha$ syn (Bennett, 2005; Wislet-Gendebien et al., 2006). Although $\alpha$ syn was initially recognized as a cytoplasmic protein (Iwai et al., 1995), several lines of evidence have also documented localization of $\alpha$ syn in the nucleus (Goers et al., 2003; Zhang et al., 2008). Interestingly, a previous study indicated that nuclear $\alpha$ syn promoted neurotoxicity, and conversely, cytoplasmic localization of $\alpha$ syn was neuroprotective (Kontopoulos et al., 2006). In the present study, the cytoplasmic localization of $\alpha$ syn that prevented $\mathrm{MPP}^{+}$-induced cell death partially confirmed this finding (Fig. 2). Additionally, $\alpha$ syn has been shown to function as a negative mediator of DA synthesis via interactions with TH and/or PP2A to inhibit TH activity (Perez et al., 2002; X. Peng et al., 2005). We also reported that PKC $\delta$ negatively regulates TH activity by binding and phosphorylating PP2A (Zhang et al., 2007a). In the present study, we demonstrated that $\alpha$ syn represses PKC $\delta$ transcription, suggesting that $\alpha$ syn-mediated repression of PKC $\delta$ may alter DA synthesis. Importantly, we found a reduced PKC $\delta$ expression in $\alpha$ syn-transgenic mouse models, indicating the $\alpha$ syn overexpression represses the proapoptotic kinase PKC $\delta$ in vivo. These results may explain why $\alpha$ synoverexpressing mice are resistant to neurodegeneration in dopaminergic neurons despite the high accumulation of the protein in the substantia nigra.

Although our results indicate that p300 pathway is likely the major pathway controlling the downregulation of PKC $\delta$ in transgenic animal, it is possible that other PKC $\delta$ downregulation mechanisms come into play, acting alone or in concert, since overexpression of $\alpha$ syn was found to significantly alter multiple signaling pathways, including stress response, transcription factors, apoptosis-inducing molecules, and membrane-bound proteins (Baptista et al., 2003). Moreover, $\alpha$ syn has been shown to be able to directly associate with histones and inhibit histone acetylation, suggesting a direct role of the protein in regulation of gene transcription (Goers et al., 2003; Kontopoulos et al., 2006).

We report here for the first time the repression of the PKC $\delta$ gene by $\alpha$ syn in dopaminergic neurons mediated through the transcription factors $\mathrm{NF} \kappa \mathrm{B}$ and $\mathrm{p} 300$. Our results show that $\alpha$ syn inhibits NF $\kappa$ B transcriptional activity at the level of p 65 acetyla- 
tion, without affecting $\mathrm{NF} \kappa \mathrm{B} / \mathrm{I} \kappa \mathrm{B} \alpha$ nuclear translocation, $\mathrm{I} \kappa \mathrm{B} \alpha$ degradation, or $\mathrm{NF} \kappa \mathrm{B} / \mathrm{I} \kappa \mathrm{B} \alpha$ protein levels. It should be noted, however, that acetylation of $\mathrm{p} 65$ to mediate $\mathrm{NF} \kappa \mathrm{B}$ transcriptional activity may be more complex, as acetylation of discrete lysine sites may regulate different nuclear functions (Chen et al., 2002). Independent of regulation of p65 acetylation levels, modulation of p300/CBP-mediated acetylation of p50 has to be considered as one mechanism for the inhibition of p50 binding activity (Fig. $5 D)$ by $\alpha$ syn, because acetylation of p 50 increases its DNA binding and further induces $\mathrm{NF} \kappa \mathrm{B}$ transcriptional activity (Deng et al., 2003). Moreover, analysis of the PKC $\delta$ promoter has uncovered multiple potential transcription factor sites. Therefore, it is also possible that one or more of those factors may contribute to the attenuation of PKC $\delta$ expression by $\alpha$ syn.

An important finding of this study is that $\alpha$ syn specifically decreases p300 protein in vivo and in vitro. Our model introduces loss of p300 as an underlying mechanism of its reduced HAT activity. p300 appears to play at least two major roles in $\alpha$ synmediated suppression of PKC $\delta$. First, loss of p300 proteins and its corresponding HAT activity reduces $\mathrm{p} 65$ acetylation and binding activity to $\mathrm{PKC} \delta$ promoter, thereby resulting in downregulation of PKC $\delta$. Second, PKC $\delta$ gene expression itself may be dependent on $\mathrm{p} 300$. Thus, the depletion of $\mathrm{p} 300$ proteins would decrease the recruitment and binding of $\mathrm{p} 300$ onto $\mathrm{PKC} \delta$ promoter, and subsequently may interfere with the interactions between p300 and $\mathrm{NF} \kappa \mathrm{B}$ or other transcriptional complexes, eventually blocking $\mathrm{PKC} \delta$ transcription. However, the mechanism by which $\alpha$ syn disrupts the p300 protein is unclear. Our unpublished data indicate that $\alpha$ syn does not likely regulate p300 protein level at the transcriptional level. Additional investigation should reveal whether $\alpha$ syn inhibits $\mathrm{p} 300$ protein by an alternative mechanism, such as degradation mediated by proteasome as reported previously (Poizat et al., 2005).

It is important to note that regulation of acetylation of p65 could not be limited to the acetyltransferase activities of p300 and CBP because deacetylation reactions can also influence the overall acetylation status of $\mathrm{NF} \kappa \mathrm{B}$. In fact, it has been reported that p65 is reversibly acetylated by p300 and CBP and subsequently deacetylated by HDACs, most notably, HDAC3 (Kiernan et al., 2003). Therefore, the contribution of HDACs to the inhibition of p65 acetylation by $\alpha$ syn remains to be elucidated. In addition to acetylation, p65 is also regulated by the modification of phosphorylation, which can potentiate the transcription by enhancing p65 association with the p300/CBP coactivator (Zhong et al., 2002). The influence of $\alpha$ syn on NF $\kappa \mathrm{B}$ transactivation by alteration of p65 phosphorylation status is yet to be determined.

In summary, our results are based on multiple independent techniques that together elucidate the molecular and cellular mechanisms underlying the downregulation of PKC $\delta$ by $\alpha$ syn. These findings expand the role of $\alpha$ syn in neuroprotection and have important implications for the development of novel drug therapies for PD.

\section{References}

Albani D, Peverelli E, Rametta R, Batelli S, Veschini L, Negro A, Forloni G (2004) Protective effect of TAT-delivered alpha-synuclein: relevance of the C-terminal domain and involvement of HSP70. FASEB J 18:1713-1715.

Alves Da Costa C, Paitel E, Vincent B, Checler F (2002) Alpha-synuclein lowers p53-dependent apoptotic response of neuronal cells. Abolishment by 6-hydroxydopamine and implication for Parkinson's disease. J Biol Chem 277:50980-50984.

Anantharam V, Kitazawa M, Wagner J, Kaul S, Kanthasamy AG (2002) Caspase-3-dependent proteolytic cleavage of protein kinase $\mathrm{C} \delta$ is essen- tial for oxidative stress-mediated dopaminergic cell death after exposure to methylcyclopentadienyl manganese tricarbonyl. J Neurosci 22:1738-1751.

Andrä K, Abramowski D, Duke M, Probst A, Wiederhold KH, Bürki K, Goedert M, Sommer B, Staufenbiel M (1996) Expression of APP in transgenic mice: a comparison of neuron-specific promoters. Neurobiol Aging 17:183-190.

Arif M, Pradhan SK, Thanuja GR, Vedamurthy BM, Agrawal S, Dasgupta D, Kundu TK (2009) Mechanism of p300 specific histone acetyltransferase inhibition by small molecules. J Med Chem 52:267-277.

Balasubramanyam K, Swaminathan V, Ranganathan A, Kundu TK (2003) Small molecule modulators of histone acetyltransferase p300. J Biol Chem 278:19134-19140.

Balasubramanyam K, Altaf M, Varier RA, Swaminathan V, Ravindran A, Sadhale PP, Kundu TK (2004) Polyisoprenylated benzophenone, garcinol, a natural histone acetyltransferase inhibitor, represses chromatin transcription and alters global gene expression. J Biol Chem 279: 33716-33726.

Baptista MJ, O’Farrell C, Daya S, Ahmad R, Miller DW, Hardy J, Farrer MJ, Cookson MR (2003) Co-ordinate transcriptional regulation of dopamine synthesis genes by alpha-synuclein in human neuroblastoma cell lines. J Neurochem 85:957-968.

Bennett MC (2005) The role of alpha-synuclein in neurodegenerative diseases. Pharmacol Ther 105:311-331.

Brodie C, Blumberg PM (2003) Regulation of cell apoptosis by protein kinase $\mathrm{C} \delta$. Apoptosis 8:19-27.

Burke RE (2008) Programmed cell death and new discoveries in the genetics of parkinsonism. J Neurochem 104:875-890.

Cartharius K, Frech K, Grote K, Klocke B, Haltmeier M, Klingenhoff A, Frisch M, Bayerlein M, Werner T (2005) MatInspector and beyond: promoter analysis based on transcription factor binding sites. Bioinformatics 21:2933-2942.

Chan HM, La Thangue NB (2001) p300/CBP proteins: HATs for transcriptional bridges and scaffolds. J Cell Sci 114:2363-2373.

Chandra S, Gallardo G, Fernández-Chacón R, Schlüter OM, Südhof TC (2005) Alpha-synuclein cooperates with CSPalpha in preventing neurodegeneration. Cell 123:383-396.

Chen LF, Fischle W, Verdin E, Greene WC (2001) Duration of nuclear NFkappaB action regulated by reversible acetylation. Science 293:16531657.

Chen LF, Mu Y, Greene WC (2002) Acetylation of RelA at discrete sites regulates distinct nuclear functions of NF-kappaB. EMBO J 21:6539-6548.

Chen YL, Law PY, Loh HH (2006) Sustained activation of phosphatidylinositol 3-kinase/Akt/nuclear factor kappaB signaling mediates G proteincoupled delta-opioid receptor gene expression. J Biol Chem 281:3067-3074.

Clarkson ED, Edwards-Prasad J, Freed CR, Prasad KN (1999) Immortalized dopamine neurons: a model to study neurotoxicity and neuroprotection. Proc Soc Exp Biol Med 222:157-163.

Clayton DF, George JM (1998) The synucleins: a family of proteins involved in synaptic function, plasticity, neurodegeneration and disease. Trends Neurosci 21:249-254.

Cooper AA, Gitler AD, Cashikar A, Haynes CM, Hill KJ, Bhullar B, Liu K, Xu K, Strathearn KE, Liu F, Cao S, Caldwell KA, Caldwell GA, Marsischky G, Kolodner RD, Labaer J, Rochet JC, Bonini NM, Lindquist S (2006) Alpha-synuclein blocks ER-Golgi traffic and Rab1 rescues neuron loss in Parkinson's models. Science 313:324-328.

Dauer W, Przedborski S (2003) Parkinson's disease: mechanisms and models. Neuron 39:889-909.

de Erausquin GA, Hyrc K, Dorsey DA, Mamah D, Dokucu M, Mascó DH, Walton T, Dikranian K, Soriano M, García Verdugo JM, Goldberg MP, Dugan LL (2003) Nuclear translocation of nuclear transcription factorkappa B by alpha-amino-3-hydroxy-5-methyl-4-isoxazolepropionic acid receptors leads to transcription of p53 and cell death in dopaminergic neurons. Mol Pharmacol 63:784-790.

Deng WG, Zhu Y, Wu KK (2003) Up-regulation of p300 binding and p50 acetylation in tumor necrosis factor-alpha-induced cyclooxygenase-2 promoter activation. J Biol Chem 278:4770-4777.

DeVries TA, Neville MC, Reyland ME (2002) Nuclear import of PKCdelta is required for apoptosis: identification of a novel nuclear import sequence. EMBO J 21:6050-6060. 
Duan J, Friedman J, Nottingham L, Chen Z, Ara G, Van Waes C (2007) Nuclear factor-kappaB p65 small interfering RNA or proteasome inhibitor bortezomib sensitizes head and neck squamous cell carcinomas to classic histone deacetylase inhibitors and novel histone deacetylase inhibitor PXD101. Mol Cancer Ther 6:37-50.

Ghosh A, Chandran K, Kalivendi SV, Joseph J, Antholine WE, Hillard CJ, Kanthasamy A, Kanthasamy A, Kalyanaraman B (2010) Neuroprotection by a mitochondria-targeted drug in a Parkinson's disease model. Free Radic Biol Med 49:1674-1684.

Giasson BI, Duda JE, Quinn SM, Zhang B, Trojanowski JQ, Lee VM (2002) Neuronal alpha-synucleinopathy with severe movement disorder in mice expressing A53T human alpha-synuclein. Neuron 34:521-533.

Goers J, Manning-Bog AB, McCormack AL, Millett IS, Doniach S, Di Monte DA, Uversky VN, Fink AL (2003) Nuclear localization of alphasynuclein and its interaction with histones. Biochemistry 42:8465-8471.

Greenamyre JT, Hastings TG (2004) Biomedicine. Parkinson's—divergent causes, convergent mechanisms. Science 304:1120-1122.

Gustin JA, Ozes ON, Akca H, Pincheira R, Mayo LD, Li Q, Guzman JR, Korgaonkar CK, Donner DB (2004) Cell type-specific expression of the IkappaB kinases determines the significance of phosphatidylinositol 3-kinase/Akt signaling to NF-kappa B activation. J Biol Chem 279:1615-1620.

Hashimoto M, Hsu LJ, Rockenstein E, Takenouchi T, Mallory M, Masliah E (2002) alpha-Synuclein protects against oxidative stress via inactivation of the c-Jun N-terminal kinase stress-signaling pathway in neuronal cells. J Biol Chem 277:11465-11472.

Hatcher JM, Pennell KD, Miller GW (2008) Parkinson's disease and pesticides: a toxicological perspective. Trends Pharmacol Sci 29:322-329.

Iwai A, Masliah E, Yoshimoto M, Ge N, Flanagan L, de Silva HA, Kittel A, Saitoh T (1995) The precursor protein of non-A beta component of Alzheimer's disease amyloid is a presynaptic protein of the central nervous system. Neuron 14:467-475.

Jensen PJ, Alter BJ, O'Malley KL (2003) Alpha-synuclein protects naive but not dbcAMP-treated dopaminergic cell types from 1-methyl-4phenylpyridinium toxicity. J Neurochem 86:196-209.

Jing Q, Huang S, Guth S, Zarubin T, Motoyama A, Chen J, Di Padova F, Lin SC, Gram H, Han J (2005) Involvement of microRNA in AU-rich element-mediated mRNA instability. Cell 120:623-634.

Kanthasamy AG, Kitazawa M, Kanthasamy A, Anantharam V (2003) Role of proteolytic activation of protein kinase Cdelta in oxidative stressinduced apoptosis. Antioxid Redox Signal 5:609-620.

Kanthasamy AG, Anantharam V, Zhang D, Latchoumycandane C, Jin H, Kaul S, Kanthasamy A (2006) A novel peptide inhibitor targeted to caspase-3 cleavage site of a proapoptotic kinase protein kinase $\mathrm{C}$ delta (PKCdelta) protects against dopaminergic neuronal degeneration in Parkinson's disease models. Free Radic Biol Med 41:1578-1589.

Kaul S, Kanthasamy A, Kitazawa M, Anantharam V, Kanthasamy AG (2003) Caspase-3 dependent proteolytic activation of protein kinase $\mathrm{C}$ delta mediates and regulates 1-methyl-4-phenylpyridinium (MPP+)-induced apoptotic cell death in dopaminergic cells: relevance to oxidative stress in dopaminergic degeneration. Eur J Neurosci 18:1387-1401.

Kaul S, Anantharam V, Yang Y, Choi CJ, Kanthasamy A, Kanthasamy AG (2005a) Tyrosine phosphorylation regulates the proteolytic activation of protein kinase Cdelta in dopaminergic neuronal cells. J Biol Chem 280:28721-28730.

Kaul S, Anantharam V, Kanthasamy A, Kanthasamy AG (2005b) Wild-type alpha-synuclein interacts with pro-apoptotic proteins $\mathrm{PKCdelta}$ and $\mathrm{BAD}$ to protect dopaminergic neuronal cells against MPP + -induced apoptotic cell death. Brain Res Mol Brain Res 139:137-152.

Kiernan R, Brès V, Ng RW, Coudart MP, El Messaoudi S, Sardet C, Jin DY, Emiliani S, Benkirane M (2003) Post-activation turn-off of NF-kappa B-dependent transcription is regulated by acetylation of p65. J Biol Chem 278:2758-2766.

Kitazawa M, Anantharam V, Kanthasamy AG (2003) Dieldrin induces apoptosis by promoting caspase-3-dependent proteolytic cleavage of protein kinase Cdelta in dopaminergic cells: relevance to oxidative stress and dopaminergic degeneration. Neuroscience 119:945-964.

Kitazawa M, Anantharam V, Yang Y, Hirata Y, Kanthasamy A, Kanthasamy AG (2005) Activation of protein kinase C delta by proteolytic cleavage contributes to manganese-induced apoptosis in dopaminergic cells: protective role of Bcl-2. Biochem Pharmacol 69:133-146.

Kontopoulos E, Parvin JD, Feany MB (2006) Alpha-synuclein acts in the nucleus to inhibit histone acetylation and promote neurotoxicity. Hum Mol Genet 15:3012-3023.

Latchoumycandane C, Anantharam V, Kitazawa M, Yang Y, Kanthasamy A, Kanthasamy AG (2005) Protein kinase Cdelta is a key downstream mediator of manganese-induced apoptosis in dopaminergic neuronal cells. J Pharmacol Exp Ther 313:46-55.

Lee DW, Rajagopalan S, Siddiq A, Gwiazda R, Yang L, Beal MF, Ratan RR, Andersen JK (2009) Inhibition of prolyl hydroxylase protects against 1-methyl-4-phenyl-1,2,3,6-tetrahydropyridine-induced neurotoxicity: model for the potential involvement of the hypoxia-inducible factor pathway in Parkinson disease. J Biol Chem 284:29065-29076.

Lee MK, Stirling W, Xu Y, Xu X, Qui D, Mandir AS, Dawson TM, Copeland NG, Jenkins NA, Price DL (2002) Human alpha-synuclein-harboring familial Parkinson's disease-linked Ala-53 $\rightarrow$ Thr mutation causes neurodegenerative disease with alpha-synuclein aggregation in transgenic mice. Proc Natl Acad Sci U S A 99:8968-8973.

Leng Y, Chuang DM (2006) Endogenous $\alpha$-synuclein is induced by valproic acid through histone deacetylase inhibition and participates in neuroprotection against glutamate-induced excitotoxicity. J Neurosci 26:75027512.

Li LC, Dahiya R (2002) MethPrimer: designing primers for methylation PCRs. Bioinformatics 18:1427-1431.

Manning-Bog AB, McCormack AL, Purisai MG, Bolin LM, Di Monte DA (2003) $\alpha$-Synuclein overexpression protects against paraquat-induced neurodegeneration. J Neurosci 23:3095-3099.

Mantelingu K, Kishore AH, Balasubramanyam K, Kumar GV, Altaf M, Swamy SN, Selvi R, Das C, Narayana C, Rangappa KS, Kundu TK (2007) Activation of p300 histone acetyltransferase by small molecules altering enzyme structure: probed by surface-enhanced Raman spectroscopy. J Phys Chem B 111:4527-4534.

Matsuoka Y, Vila M, Lincoln S, McCormack A, Picciano M, LaFrancois J, Yu X, Dickson D, Langston WJ, McGowan E, Farrer M, Hardy J, Duff K, Przedborski S, Di Monte DA (2001) Lack of nigral pathology in transgenic mice expressing human alpha-synuclein driven by the tyrosine hydroxylase promoter. Neurobiol Dis 8:535-539.

Monti B, Polazzi E, Batti L, Crochemore C, Virgili M, Contestabile A (2007) Alpha-synuclein protects cerebellar granule neurons against 6-hydroxydopamine-induced death. J Neurochem 103:518-530.

Morgenstern B, Dress A, Werner T (1996) Multiple DNA and protein sequence alignment based on segment-to-segment comparison. Proc Natl Acad Sci U S A 93:12098-12103.

Morgenstern B, Frech K, Dress A, Werner T (1998) DIALIGN: finding local similarities by multiple sequence alignment. Bioinformatics 14:290-294.

Nakatani F, Tanaka K, Sakimura R, Matsumoto Y, Matsunobu T, Li X, Hanada M, Okada T, Iwamoto Y (2003) Identification of p21WAF1/CIP1 as a direct target of EWS-Fli1 oncogenic fusion protein. J Biol Chem 278:15105-15115.

Norris EH, Giasson BI, Lee VM (2004) Alpha-synuclein: normal function and role in neurodegenerative diseases. Curr Top Dev Biol 60:17-54.

Ostrerova N, Petrucelli L, Farrer M, Mehta N, Choi P, Hardy J, Wolozin B (1999) $\alpha$-Synuclein shares physical and functional homology with 143-3 proteins. J Neurosci 19:5782-5791.

Outeiro TF, Lindquist S (2003) Yeast cells provide insight into alphasynuclein biology and pathobiology. Science 302:1772-1775.

Patrone G, Puppo F, Cusano R, Scaranari M, Ceccherini I, Puliti A, Ravazzolo R (2000) Nuclear run-on assay using biotin labeling, magnetic bead capture and analysis by fluorescence-based RT-PCR. Biotechniques 29:10121014, 1016-1017.

Peng J, Stevenson FF, Doctrow SR, Andersen JK (2005) Superoxide dismutase/catalase mimetics are neuroprotective against selective paraquatmediated dopaminergic neuron death in the substantial nigra: implications for Parkinson disease. J Biol Chem 280:29194-29198.

Peng X, Tehranian R, Dietrich P, Stefanis L, Perez RG (2005) Alphasynuclein activation of protein phosphatase $2 \mathrm{~A}$ reduces tyrosine hydroxylase phosphorylation in dopaminergic cells. J Cell Sci 118:3523-3530.

Perez RG, Waymire JC, Lin E, Liu JJ, Guo F, Zigmond MJ (2002) A role for $\alpha$-synuclein in the regulation of dopamine biosynthesis. J Neurosci 22:3090-3099.

Poizat C, Puri PL, Bai Y, Kedes L (2005) Phosphorylation-dependent degradation of $\mathrm{p} 300$ by doxorubicin-activated $\mathrm{p} 38$ mitogen-activated protein kinase in cardiac cells. Mol Cell Biol 25:2673-2687.

Rathke-Hartlieb S, Kahle PJ, Neumann M, Ozmen L, Haid S, Okochi M, 
Haass C, Schulz JB (2001) Sensitivity to MPTP is not increased in Parkinson's disease-associated mutant alpha-synuclein transgenic mice. J Neurochem 77:1181-1184.

Seo JH, Rah JC, Choi SH, Shin JK, Min K, Kim HS, Park CH, Kim S, Kim EM, Lee SH, Lee S, Suh SW, Suh YH (2002) Alpha-synuclein regulates neuronal survival via $\mathrm{Bcl}-2$ family expression and $\mathrm{PI} /$ Akt kinase pathway. FASEB J 16:1826-1828.

Sidhu A, Wersinger C, Moussa CE, Vernier P (2004) The role of alphasynuclein in both neuroprotection and neurodegeneration. Ann N Y Acad Sci 1035:250-270.

Souto JA, Benedetti R, Otto K, Miceli M, Alvarez R, Altucci L, de Lera AR (2010) New anacardic acid-inspired benzamides: histone lysine acetyltransferase activators. ChemMedChem 5:1530-1540.

Spillantini MG, Crowther RA, Jakes R, Hasegawa M, Goedert M (1998) $\alpha$-Synuclein in filamentous inclusions of Lewy bodies from Parkinson's disease and dementia with lewy bodies. Proc Natl Acad Sci U S A 95:6469-6473

Stéphan A, Davis S, Salin H, Dumas S, Mallet J, Laroche S (2002) Agedependent differential regulation of genes encoding APP and alphasynuclein in hippocampal synaptic plasticity. Hippocampus 12:55-62.

Suh KS, Tatunchak TT, Crutchley JM, Edwards LE, Marin KG, Yuspa SH (2003) Genomic structure and promoter analysis of PKC-delta. Genomics 82:57-67.

Takai D, Jones PA (2002) Comprehensive analysis of CpG islands in human chromosomes 21 and 22. Proc Natl Acad Sci U S A 99:3740-3745.

Wislet-Gendebien S, D'Souza C, Kawarai T, St George-Hyslop P, Westaway D, Fraser P, Tandon A (2006) Cytosolic proteins regulate alphasynuclein dissociation from presynaptic membranes. J Biol Chem 281:32148-32155.
Yang Y, Kaul S, Zhang D, Anantharam V, Kanthasamy AG (2004) Suppression of caspase-3-dependent proteolytic activation of protein kinase $\mathrm{C}$ delta by small interfering RNA prevents MPP +-induced dopaminergic degeneration. Mol Cell Neurosci 25:406-421.

Zafar KS, Inayat-Hussain SH, Ross D (2007) A comparative study of proteasomal inhibition and apoptosis induced in $\mathrm{N} 27$ mesencephalic cells by dopamine and MG132. J Neurochem 102:913-921.

Zhang D, Kanthasamy A, Yang Y, Anantharam V, Kanthasamy A (2007a) Protein kinase C $\delta$ negatively regulates tyrosine hydroxylase activity and dopamine synthesis by enhancing protein phosphatase-2A activity in dopaminergic neurons. J Neurosci 27:5349-5362.

Zhang D, Anantharam V, Kanthasamy A, Kanthasamy AG (2007b) Neuroprotective effect of protein kinase $\mathrm{C}$ delta inhibitor rottlerin in cell culture and animal models of Parkinson's disease. J Pharmacol Exp Ther 322:913-922.

Zhang L, Zhang C, Zhu Y, Cai Q, Chan P, Uéda K, Yu S, Yang H (2008) Semi-quantitative analysis of alpha-synuclein in subcellular pools of rat brain neurons: an immunogold electron microscopic study using a C-terminal specific monoclonal antibody. Brain Res 1244:40-52.

Zhong H, May MJ, Jimi E, Ghosh S (2002) The phosphorylation status of nuclear NF-kappa B determines its association with $\mathrm{CBP} / \mathrm{p} 300$ or HDAC-1. Mol Cell 9:625-636.

Zhou C, Huang Y, Przedborski S (2008) Oxidative stress in Parkinson's disease: a mechanism of pathogenic and therapeutic significance. Ann N Y Acad Sci 1147:93-104.

Zhu M, Qin ZJ, Hu D, Munishkina LA, Fink AL (2006) Alpha-synuclein can function as an antioxidant preventing oxidation of unsaturated lipid in vesicles. Biochemistry 45:8135-8142. 